\title{
Finansal Gelişme ve Ekonomik Performans İlişkisi: OECD Ülkeleri İçin Bir Analiz
}

\begin{abstract}
DOI: 10.26466/opus.535427
*

Hatice Armutcuoğlu Tekin ${ }^{*}-$ Mert Ural $^{* *}$

* Arş. Gör., Adnan Menderes Üniversitesi, Söke İşletme Fakültesi, Söke / Aydın / Türkiye E-Posta: hatice.armutcuoglu@adu.edu.tr ORCID: 0000-0003-4594-6417

** Prof. Dr., Dokuz Eylül Üniversitesi, İktisadi ve İdari Bilimler Fakültesi, Buca /İzmir/ Türkiye E-Posta: mert.ural@deu.edu.tr

ORCID: $\underline{0000-0003-3252-846 \mathrm{X}}$

Finansal krizlerin her bir ülke üzerinde farklı etkileri ortaya çımaktadır. Krizler, kimi ülkeleri derinden etkilerken, kimi ülkelerde oldukça az etkilidir veya etkili değildir. Bu durumunda, bu ülkelerin finansal gelişmişlik ve ekonomik performans düzeyleriyle ilgisi olduğu söylenebilir. Bu sebeple bu çalışmada küreselleşmenin yoğun yaşandığı bu dönemde finansal gelişmişlik derecesinin ve ekonomik performansin uzun dönemde ilişkili olduğu öngörülmektedir. Finansal gelişmişlik endeksi yüksek olan ülkelerin böyle zamanlarda daha kolay kaynak bulmaları sebebi ile ekonomik performansları daha yüksek olmaktadır. Ülkelerin ekonomik performansının gü̈clü olması, uluslararası yatırım yapan finansal sermaye açısından yatırım tercihi sebeplerinden biridir. Bu nedenle bu çalışmada finansal gelişmişlik ve ekonomik performansın uzun dönemli ilişkisinin, ulaşılabilir veri kısıtı sebebiyle 2006-2016 zaman aralı̆̆ında 34 OECD ülkesi için araştırılması amaçlanmıştır. Finansal gelişmişliği ölçmek için finansal gelişme endeksi, ekonomik performansı ölçmek için ise Hanke'nin uyarladığı Barro sefalet endeksi kullanılmıştır. Değişkenler arasındaki uzun dönem ilişkisinin varlı̆̆ını tespit etmek amacıyla, yapısal kırılmaları dikkate alan Westerlund panel eşbütünleşme analizi yöntemi uygulanmıştır. Sonuç olarak, finansal gelişme ve ekonomik performans uzun dönemde ilişkilidir.
\end{abstract}

Öz

Anahtar Kelimeler: Finansal gelişme, Makroekonomik performans, Panel veri eşbütünleşme analizi. 


\title{
Financial Development and Economic Performance Relationship: An Analysis For OECD Countries
}

\begin{abstract}
Financial crises have different effects on each country. While crises affect some countries deeply, they have little or no impact on others. In this case, it can be said that these countries' financial development and economic performance levels are related. For this reason, it is predicted that financial development and economic performance are related to long term in this period where globalization is deep. Countries with high financial development index have higher economic performance due to easier finding sources at such times. Strong economic performance of countries is one of the reasons of investment preference in terms of financial capital investing internationally. Therefore, in this case aims to investigate the long-term relationship between financial development and economic performance for 34 OECD countries in the period of 2006-2016 due to accessible data constraint. While financial development index was used to measure financial development, Barro misery index adapted by Hanke was used to measure economic performance. In order to determine the long-term relationship between variables, Westerlund panel cointegration analysis method considering structural breaks was applied. As a result, financial development and economic performance are related in the long term.
\end{abstract}

Keywords: Financial development, Macroeconomic performance, Panel data coentegration analysis. 


\section{Giriş}

Finansal gelişme, finansal piyasaların genişlemesi ve gelişmesi olarak ele alınmasının yanı sıra finansal serbestleşme ve finansal inovasyonların ortaya çıkarılması olarak da değerlendirilmektedir. Paranın kullanılmaya başlaması, bunun yerini alan kredi kartları ve sanal kartlar, mübadele işlemlerinde büyük kolaylıklar sağlayarak ticaretin gelişmesinde ve artmasında oldukça etkili olmuştur. Artan teknoloji ile borsalarda işlem yapılması, dünyanın bir ucundan diğer ucuna şirketler kurularak yatırımların yapılması, bir ülkedeki bireyin tasarrufunun başka bir ülkede yatırım amaçlı faiz karşıllğı kullandırılması gerçek olmuş, bu işlemler için harcanan zaman ise sanal işlemler sayesinde saniyelere düşmüştür. Finansal piyasalar geliştikçe ekonomik işlemler kolaylaşmış piyasaların entegrasyonu artmıştır. Ancak artan entegrasyon ise, bir ülkede ortaya çıkan finansal krizin diğer ülkeleri etkilemesini de kolaylaştırmıştır. Dolayısıyla finansal gelişme ülkelerin makroekonomik performansına etki etmiştir.

Finansal gelişme seviyesinin farklılık göstermesi birçok faktöre bağlıdır. Yatırımcıların ve tasarruf sahiplerinin riski azaltma ve getiriyi arttırma arzusu, firmaların yeni teknolojiler ile müşteri memnuniyetini arttırma isteği, tasarruf sahiplerinin ve yatırımcların maliyetleri azaltma ve verimliliği arttırma arzusu, finansal piyasadaki organların yasal mevzuatın yarattığı baskıdan kaçınma isteği, likiditeyi arttırma ve işlem kolaylığı sağlama isteği, dini inançlar, ekonomik göstergeler ve yatırımc1 çekme becerisi, finansal krizler; finansal gelişmeyi etkileyen faktörler olarak sıralanabilir. Huang (2005) çalışmasında bir ülkenin finansal gelişme seviyesini o ülkenin kurumsal kalitesinin, coğrafi özelliklerinin, makroekonomik politikalarının, ülkedeki insanların gelir düzeylerinin ve kültürel özelliklerinin belirlediğini ifade etmiştir. Ağır, Peker ve Kar (2009) literatür taraması olarak gerçekleştirdikleri çalışmalarında ülkelerin finansal gelişmişlik seviyelerinin neden birbirinden farklı olduğunu açıklamayı amaçlamışlar ve finansal gelişmenin belirleyicilerini araştırmışlardır. Bunun sonucunda ekonomik büyüme, finansal liberalizasyon, diş ticaretin serbestleşmesi, sermaye hareketlerinin serbestleşmesi, kurumsal yapı ve kalkınma, kamunun finansal sektördeki payı, piyasadaki denetleme mekanizmalarının etkinliği, mevduat 
sigortasının varlığı, zorunlu karşılık oranlarının uygulanması, yasal mevzuatlar, makroekonomik politika uygulamaları ve politika tutarlılıklarındaki değişikliklerden dolayı ülkelerin finansal gelişmişliklerinin birbirinden farklı olduğu sonucuna varmışlardır.

Büyüme oranı, işsizlik oranı ve enflasyon makroekonominin performansını gösteren üç temel göstergedir. Ekonomik performansı güçlü olan ülkeler, finansal yatırımcı ve üretici açısından da önemli olup, genelde finansal gelişmişliği yüksek olan ülkelerdir. Bu bağlamda bu çalışmada finansal gelişme ve ekonomik performansın uzun dönemde ilişkisinin OECD ülkeleri için hem veriler ile hem de Westerlund yapısal kırılmaları dikkate alan eşbütünleşme analizi ile tespit edilip değerlendirilmesi amaçlanmıştır. Literatürde finansal gelişme-ekonomik performans ilişkisini araştıran çalışmalarda, ekonomik performansın göstergesi olarak genelde sadece ekonomik büyüme oranı ele alınmaktadır, ancak bunun yanıltıcı sonuçlarının olabileceği düşünülmektedir. Nihayetinde gelişmiş ülkeler an itibariyle yüksek GSYİH rakamlarına sahiptir, gelişmekte olan ülkelerin ise GSYİH seviyeleri daha düşüktür. Ekonomik büyüme rakamları bu sebeple genel olarak gelişmekte olan ve/veya yükselen piyasa ekonomilerinde daha yüksektir. Bunun için bu çalışmada ekonomik performans endeksi, Barro (1999)'nun hükümet performanslarını kıyaslamak amacıyla oluşturduğu sefalet endeksi göstergeleri olan büyüme oranı, işsizlik oranı, enflasyon oranı ve uzun dönem faiz oranı değişkenleri ile oluşturulmuştur. Enflasyon ve işsizlik oranlarına bakıldığında ise bu oranlar gelişmekte olan ülkelerde daha yüksektir. Kriz dönemlerinde genel anlamda bu göstergelerden büyüme azalma eğilimine girerken, enflasyon ve işsizlik ise artma eğilimine girer. Uzun vadeli faiz oranı, ülkelerin borçlanmak için karşı tarafa olan ödeme riskinin fiyatını gösterdiğinden performans göstergelerinden biri olarak değerlendirilir. Literatürde bunların yanında cari denge, ödemeler dengesi, bütçe dengesi, yatırım/GSYİH, kamu borcu/GSYİH, dış borç/GSYİH, rezervler/dış borç, doğrudan yabancı yatırımlar/GSYİH, portföy yatırımları/GSYİH gibi alternatif değişkenlerin kullanıldı̆̆ çalışmalarda mevcuttur (Şanlısoy ve Çetin (2016); Benlialper vd. (2016)). 


\section{Teori ve literatür özeti}

$\mathrm{Bu}$ çalışmada teori ve literatür üç başlık atında incelenmiştir. Öncelikle finansal gelişmişliği ve ekonomik performansın ölçülmesine yönelik literatür taraması yapılmıştır. Daha sonra finansal gelişme ve ekonomik performans ilişkisine yönelik teorik çerçeveye yer verilmiştir.

\section{Finansal gelişmenin ölçülmesi ve literatür özeti}

Literatürde finansal gelişme için yapılan ampirik çalışmaların çoğu, ekonomik büyüme, istikrar ve adaletsizlik üzerinedir. Vekil değişken olarak da genellikle finansal derinliğin iki ölçüsü olan özel sektör kredilerinin GSYİH'ya oranı ve sermaye piyasası kapitalizasyonunun GSYİH'ya oranı kullanılmaktadır. Ancak finansal gelişmeyi sadece bu iki değişkenle ele almak finansal gelişmenin kapsamını daraltmaktadır. IMF bu eksikliği gidermek için "Rethinking Financial Deepening: Stability and Growth in Emerging Markets" adlı çalışmada finansal gelişme endeksini geliştirmiştir. Finansal gelişme endeksi hem finansal kurumlara hem de menkul kıymetler piyasasına ait; finansal derinlik, finansal erişim ve finansal etkinlik başlıkları altında birden çok gösterge ile oluşturulmaktadır. IMF, finansal gelişme endeksini oluştururken kullandıkları değişkenlerin sınıflandırmasını Şema 1'e göre yapmaktadır.

Şema 1'de gösterilen derinlik, piyasa ve kurumların boyutunu ve likiditesini; erişim, bireylerin ve şirketlerin finansal hizmetlere erişim kolaylığını; etkinlik ise, sermaye piyasalarının işlem düzeyini ve kurumların sürdürülebilir gelir ve düşük maliyet ile finansal hizmet sağlama yeteneğini ölçen göstergeleri içermektedir. Bu endeks 1980'den itibaren yıllık olarak 180 ülke için hesaplanmaktadır (IMF, 2018).

Finansal gelişme endeksi Şema 1'de görüldüğü üzere, finansal kurumları ve menkul kıymetler piyasasını içeren geniş kapsamlı bir endekstir. Finansal kurumlar, bankalar, sigorta şirketleri, yatırım fonları, emeklilik fonları ve banka dışındaki diğer finansal kurumlardan oluşurken, menkul kıymetler piyasası temel olarak hisse senedi ve tahvil piyasasından oluşmaktadır. Finansal gelişme endeksini oluşturmak için kullanılan göstergeler ise Tablo 1'de özetlenmiştir. 


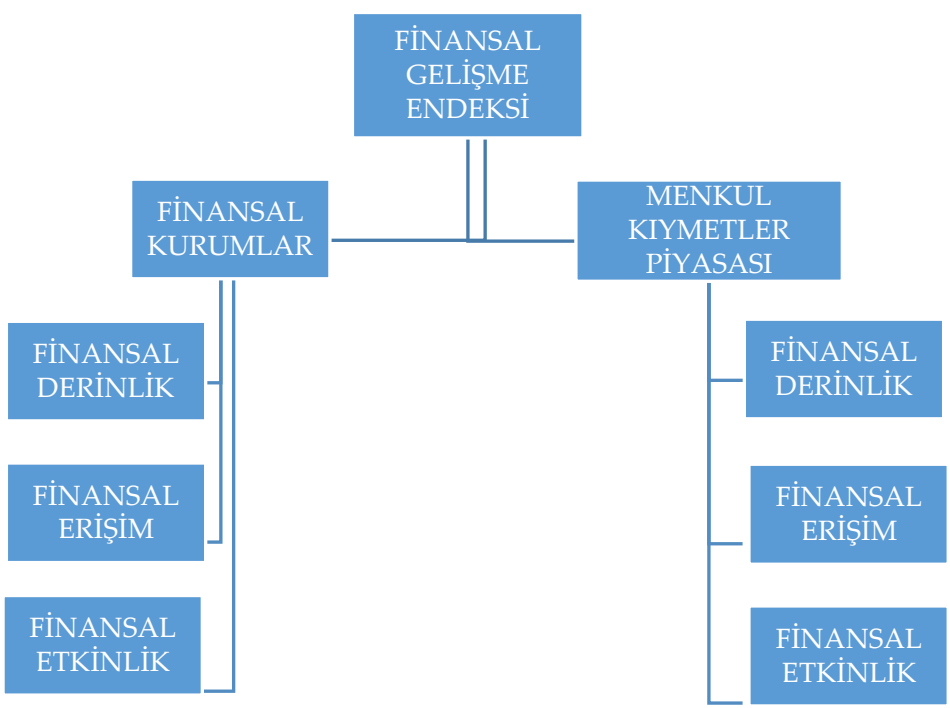

Şema 1. Finansal Gelişme Endeksi İçin Kullanılan Değişkenlerin Sınıflandırılması, IMF (2018).

Tablo 1. Finansal Gelişme Endeksinde Kullanılan Değişkenler

\begin{tabular}{|c|c|c|}
\hline \multicolumn{3}{|c|}{ Finansal Gelişme Endeksi } \\
\hline & Finansal Kurumlar & Menkul Kiymetler Piyasası \\
\hline & $\begin{array}{ll}\text { 1. } & \text { Özel sektör kredileri/GSYİH } \\
\text { 2. } & \text { Emeklilik fonu varlıklar//GSYİH } \\
\text { 3. } & \text { Yatırım fonu varlıkları/GSYİH } \\
\text { 4. } & \text { Sigorta primleri(Hayat sigortası } \\
\text { vd.)/GSYİH }\end{array}$ & $\begin{array}{ll}\text { 1. } & \begin{array}{l}\text { Sermaye piyasası kapitalizasy- } \\
\text { onu/GSYİH }\end{array} \\
\text { 2. Hisse senedi işlem hacmi/GSYİH } \\
\text { 3. Uluslararası devlet iç borçlanma se- } \\
\text { netleri/GSYİH } \\
\text { 4. Finansal olmayan uluslararası şir- } \\
\text { ketlerin borçlanma senetleri top- } \\
\text { lamı/GSYİH }\end{array}$ \\
\hline 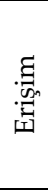 & $\begin{array}{l}\text { 1. } 100000 \text { yetişkin başına düşen ticari } \\
\text { banka şube sayısı } \\
\text { 2. } 100000 \text { yetişkin kişi başına düşen } \\
\text { ATM sayısı }\end{array}$ & $\begin{array}{l}\text { 1. En büyük } 10 \text { şirket dişındaki piyasa } \\
\text { kapitalizasyonu/Toplam kapitaliza- } \\
\text { syon } \\
\text { 2. Hisse senedi ihraç eden şirketlerin top- } \\
\text { lam sayısı }\end{array}$ \\
\hline $\begin{array}{l}\text { 泟 } \\
\text { 站 }\end{array}$ & $\begin{array}{ll}\text { 1. } & \text { Net faiz marjı } \\
\text { 2. } & \text { Mevduat kar marjı } \\
\text { 3. } & \text { Faiz dışı gelir/Toplam gelir } \\
\text { 4. } & \text { Sabit maliyetler/Toplam maliyetler } \\
\text { 5. } & \text { Aktif karlılı̆̆ } \\
\text { 6. } & \text { Özsermaye karlılığı }\end{array}$ & $\begin{array}{l}\text { 1. Hisse senedi piyasası devir hızı } \\
\text { (Hisse senedi işlem hacmi/Toplam } \\
\text { kapitalizasyon) }\end{array}$ \\
\hline
\end{tabular}

Kaynak: Sahay vd. (2015). "Rethinking Financial Deepening: Stability and Growth in Emerging Markets". IMF Staff Discussion Notes (SDNs). 
$\mathrm{Bu}$ endeks temel bileşenler analizi yöntemi ile IMF tarafından hazırlanmakta olup, her bir gösterge 0 ile 1 arasında normalleştirilmiştir. Ani değişimleri engellemek adına veriler \%95 güven aralığında düzenlenmiştir. " 1 " değeri en yüksek finansal gelişme düzeyi, "0" değeri ise en düşük finansal gelişme düzeyini temsil etmektedir (Sahay vd. 2015, s.34).

Finansal gelişme ile ilgili yapılan çalışmalarda, finansal gelişmişliği ölçmek için birden çok gösterge kullanılmıştır. Bu göstergelerden literatürde en çok karşılaşılanlar ise, Tablo 2'de özetlenmiştir.

Tablo 2. Finansal Gelişme Göstergeleri Olarak Kullanılan Değişkenlerin Literatür Özeti

\begin{tabular}{|l|l|}
\hline $\begin{array}{l}\text { Finansal Gelişme Göstergeleri Olarak } \\
\text { Kullanılan Değişkenler }\end{array}$ & Yazarlar \\
\hline $\begin{array}{l}\text { Yurtiçi krediler/GSYIH, Yurtiçi kredi- } \\
\text { ler/GSMH }\end{array}$ & $\begin{array}{l}\text { Kar ve Pentecost (2000), Ünalmış (2002), } \\
\text { Antıntaş ve Ayrıçay (2010), Acaravcı vd. } \\
(2007)\end{array}$ \\
\hline $\begin{array}{l}\text { Özel sektör kredileri/GSYİH, Özel sektör kre- } \\
\text { dileri/GSMH }\end{array}$ & $\begin{array}{l}\text { Kar ve Pentecost (2000), Ünalmış (2002), } \\
\text { Aslan ve Korap (2006), Demir vd. (2007), } \\
\text { Mercan ve Peker (2013), Law ve Singh (2013), } \\
\text { Güngör ve Yllmaz (2008), Beck vd. (2000), } \\
\text { Sağlam ve Erataş Sönmez (2017), Durusu } \\
\text { Çiftçi vd. (2016), Rajan ve Zingales (2003). }\end{array}$ \\
\hline M2/GSYİH, M2/GSMH & $\begin{array}{l}\text { Sağlam ve Erataş Sönmez (2017), Gökdeniz } \\
\text { vd. (2003), Antıntaş ve Ayrıçay (2010), } \\
\text { Husueh vd. (2013), Graff ve Karman (2006), } \\
\text { Güngör ve Yllmaz (2008), Öztürk vd. (2010). }\end{array}$ \\
\hline M2Y/GSMH & $\begin{array}{l}\text { Güneş (2013), Ünalmış(2002), Mercan ve } \\
\text { Peker (2013), Kar vd. (2008). }\end{array}$ \\
\hline Toplam mevduatlar/GSYïH & $\begin{array}{l}\text { Kar ve Pentecost (2000), Ünalmış (2002), } \\
\text { Demir vd. (2007), Güngör ve Y1lmaz (2008), } \\
\text { Rajan ve Zingales (2003) }\end{array}$ \\
\hline $\begin{array}{l}\text { Sermaye piyasası işlem hacmi/GSYïH, } \\
\text { Semaye piyasası işlem hacmi }\end{array}$ & $\begin{array}{l}\text { Güngör ve Yılmaz (2008), Kappel (2009), Ok- } \\
\text { tayer (2007). Müslümov ve Gürsoy (2000) }\end{array}$ \\
\hline Piyasa kapitilizasyonu/GSYİH & Müslümov ve Gürsoy (2000). \\
\hline
\end{tabular}

Tablo 2'deki değişkenler dışında temel bileşenler analizi ile finansal gelişme endeksleri oluşturulmuş, faiz oranı, M1, M2, M3 ve bunların GSYİH'ya oranları vb. gibi birbirinden farklı değişkenler de vekil değişken olarak kullanılmıştır. Bu çalışmada birçok göstergeyi kapsaması 
ve düzenli bir veri seti olması sebebiyle IMF tarafından geliştirilen finansal gelişme endeksi, finansal gelişmenin göstergesi olarak kullanılmıştır.

\section{Ekonomik performansın ölçülmesi ve literatür özeti}

Ekonomik performans genel olarak bir ülkenin hedeflerine ulaşmasındaki başarı oranı olarak da değerlendirilebilir. Ancak ekonomik performans, ülkeler arası karşılaştırma çalışmalarında büyüme, işsizlik, enflasyon, faiz oranı, cari açık, dış ve iç borçlanma, sermaye giriş çıkışları, yatırımlar vb. çeşitli makroekonomik göstergeler ile oluşturulan endekslere göre de değerlendirilmiştir. Ekonomik performans genellikle hükümetlerin performanslarını kıyaslamak veya ülkeler arası karşılaştırma yapmak amacıyla literatürdeki çeşitli çalışmalara konu olmuştur.

Ülkelerarası kıyaslama yapmayı sağlayan ve ekonomik performans göstergesi olarak kabul edilen bir diğer endeks ise sefalet endeksi, diğer adıyla hoşnutsuzluk(misery index) endeksidir. Sefalet endeksi ilk olarak Arthur Okun tarafından oluşturulmuş, daha sonra Robert Barro ve Steve H. Hanke tarafından farklı formülasyonlarla kullanılmıştır (Kenton, 2018). Okun Sefalet endeksi, Arthur Okun tarafından başkan Lyndon Johnson'un isteği üzerine 1960'ların sonunda oluşturulmuştur. Bu endeks işsizlik oranı ve enflasyonun toplamı ile oluşturulur, endeks değeri arttıkça ekonomik hoşnutsuzluk artarken, ekonomik performans azalmaktadır. Bu endeksin işsizliğin ve enflasyonun ekonomi üzerinde yarattığ 1 ekonomik ve sosyal maliyeti yansıttığı varsayılır (Misery Indeks US, 2018). Barro Sefalet endeksi (bse), Amerika Başkanları Reagan ve Clinton'un dönemlerini karşılaştırmak amacıyla Robert J. Barro (1999) tarafından geliştirilmiştir. Barro (1999) önceki dönem hükümet performanslarını modelden arındırmak için Okun'un işsizlik ve enflasyon oranı değişimlerini ele alıp buna uzun dönem faiz oranlarındaki mutlak değişimi ve uzun dönem büyüme açığını (uzun dönem dengesi \%3.1 olarak almıştır) eklemiştir. Mahfi Eğilmez (2018) "Sefalet Endeksi ve Türkiye" çalışmasında Barro Sefalet Endeksini aşağıdaki denklemle ifade etmiştir.

Barro Sefalet Endeksi (bse)=(Enflasyon oranı+İssizizlik oranı+Faiz Oranı)-Büyüme Oranı 
Burada ilk üç gösterge sefaleti arttırdığ için toplanırken, büyüme oranı sefaleti azalttığı için denklemde eksi değer olarak yer alıyor. Yine bu değerin artması ekonomik performansdaki bozulmayı ifade etmektedir. Aslında bu denklem 98 ülkenin performansını değerlendirmek için Steve H. Hanke tarafından uyarlanarak oluşturulmuştur (Hanke's Annual Misery Index, 2017). Çalışma kapsamındaki ekonomik performans hesaplamaları, bu formülasyona göre yapılmıştır. Hesaplamalar mutlak değişimler üzerinden yapılmadığı için bu endeksi, Hanke sefalet endeksi olarak adlandırmak daha yerinde olacaktır. Hanke sefalet endeksinin ekonomik performans göstergesi olarak seçilmesinin sebebi, üç temel makroekonomik gösterge olan ekonomik büyüme, işsizlik oranı ve enflasyon oranını içermesinin yanı sıra ülkelerin risk göstergelerinden biri olan 10 yıllık tahvil faiz oranını içermesidir. Çalışmanın hükümetler arası ve dönemsel performans karşılaştırması olmaması, ülkeler arası bir analiz olması da bu seçimde rol oynamıştır.

Oskay (2018) da, küresel kriz sonrasında kırılgan beşli ülkelerin ekonomik performansını değerlendirmek için Barro sefalet endeksi göstergelerini kullanmıştır. Kibritçioğlu (2007) Türkiye'deki hükümetlerin makroekonomik performanslarını karşılaştırdı̆̆ı çalışmasında, "enflasyon oranı, işsizlik oranı, imalat sanayi üretim endeksi artış oranı, cari hesap fazlası/GSYİH, faiz oranı, kamu kesimi borçlanma gereği/GSYİH, cari reel efektif döviz kurunun uzun dönem denge değerinden uzaklık derecesi, döviz tevdiat hesapları/M2 para arzı, toplam dış borç stoğundaki artış oranı, İMKB ulusal 100 endeksindeki artış oranı" değişkenlerini standardize edip, bu değişkenlerin ortalamasını alarak farklı değişken bileşimlerinden oluşan beş adet performans endeksi oluşturmuştur. Al ve Baday Yıldız (2019), Güran ve Tosun (2005), Moesen ve Cherchye (1998) sihirli kare yaklaşımının göstergeleri olan enflasyon, cari denge, büyüme ve işsizlik göstergelerini kullanarak Türkiye için yıllara göre makroekonomik performans karşılaştırması yapmışlardır. Setterfield (2009) üç temel makroekonomik göstergeye ekonomik eşitsizlik ve güvensizlik değişkenlerini ekleyerek farklı ă̆ırlıklar kullanarak endeks geliştirmiştir ve ağırlıkları belirlemenin endeks oluşturmanın güvenilirliği açısından önemli olduğunu ifade etmiştir. Asher vd. (1993) sefalet endeksi değişkenlerine ek olarak yoksulluk oranı ve gelir adaletsizliği derecesini de ekleyerek farklı ağırlıklar verildiğinde sonucun 
farklılaştığını göstermişlerdir. Alesina ve Summers (1993), merkez bankası bağımsızlığı ve ekonomik performans ilişkisini araştırdıkları çalışmada makroekonomik performansı, enflasyon oranı, ortalama reel GSMH büyüme oranı, kişi başına reel GSMH, işsizlik oranı ve reel faiz oranlarının ortalamaları ve varyansları ile değerlendirmişlerdir.

\section{Finansal gelişme ve ekonomik performans ilişkisine yönelik literatür özeti}

Finansal gelişme ve ekonomik performans arasındaki ilişkiye yönelik literatür incelendiğinde, bu çalı̧̧maların ekonomik performans göstergesi olarak daha çok ekonomik büyümeyi ele aldığı tespit edilmiştir. Ancak ekonomik performansın sadece ekonomik büyüme olarak değerlendirmesinin eksik olduğu düşünülmektedir. Bu sebeple bu çalışmada büyüme, enflasyon, işsizlik oranı ve uzun dönem faiz oranını içeren ekonomik performans endeksi oluşturulmuştur. Literatür incelendiğinde finansal gelişme ile tüm bu değişkenleri içeren herhangi bir ekonomik performans ilişkisinin incelendiği bir çalışmaya rastlanmamıştır. Vivien Kappel (2009) doktora tez çalışmasında finansal gelişme ve ekonomik performans göstergeleri olarak büyüme, gelir adaletsizliği, eşitsizlik ve yoksullukla ilgili farklı modellerle tahminler gerçekleştirmiştir. Darrat vd. (2006) "Finance and Macroeconomic Performance" adlı çalışmalarında yine temel makroekonomik performans göstergesi olarak reel GSYİH büyümesini almışlar, bunun yanında sektör politikalarını belirlemede yardımcı olmak için reel tüketim ve reel yatırım büyüme oranları değişkenlerini de alarak eşbütünleşme analizi yapmışlardır. Çalışmalarında kısa dönemde finansal gelişme ekonomik performansı etkilemezken, uzun dönemde etkilemektedir sonucunu elde etmişlerdir. İbrahim (2011)'in Tayland için sermaye piyasası gelişimi ve makroekonomik performans ilişkisini VAR analizi ile inceledikleri çalışmada, makroekonomik performansı temsilen GSYİH büyüme oranını, kontrol değişkeni olarak da yatırım oranı ve enflasyon oranını kullanmışlardır. Bunun sonucunda sermaye piyasası gelişimi ile makroekonomik performansın uzun dönemde ilişkili olduğunu tespit etmişlerdir. Finansal gelişme ve ekonomik performans ilişkisini inceleyen literatür kısıtlı olduğu için çalışmada finansal gelişme-büyüme, finansal gelişme- 
enflasyon, finansal gelişme- işsizlik, finansal gelişme -faiz oranları arasındaki ilişkiler ayrı ayrı kısaca incelenmiştir. Yine yapılan literatür araştırması sonucunda finansal gelişme ve uzun dönem faiz oranı ilişkisini inceleyen herhangi bir çalışmaya rastlanmamıştır.

Finansal gelişme ekonomik gelişme kalemlerinden biri olan büyümeyi sermaye birikimi ve teknolojik gelişme kanallarıyla etkilemektedir (Seven, 2015, s.54). Finansal gelişmenin reel ekonomiyi etkileyebilmesi için finansal piyasalarda artan para hacminin reel yatırımlara kaynak sağlaması önem arz etmektedir. Finansal gelişme ekonomik büyüme ilişkisine yönelik çalışmaların temelleri King ve Levine (1993)'nin “Finans, Girişimcilik ve Büyüme Teorisi ve Amprik Uygulama" adlı çalışmalarına dayanmaktadır. Bu çalışmaya göre finansal sistem verimliliği arttırarak girişimciliği dört farklı yolla etkilemektedir. Birincisi finansal sistem en iyi projelerin seçilmesini ve iyi girişimcilerin potansiyellerini ortaya koymasını sağlar. İkincisi projeler için finansal kaynak bulunmasını kolaylaştırır. Üçüncüsü yatırımcıların inovatif eylemlerinin sonucu ortaya çıkan riskin dağıtılmasını sağlar. Son olarak finansal sistemde var olan teknolojinin üretime adapte edilmesi ile yapılan inovasyonların potansiyelinin artmasina katkıda bulunur. Bu nedenle finansal sitemin gelişmişliği girişimcilerin verimliliğini arttırarak ekonomik büyümeye katkıda bulunur. Gurley ve Shaw (1955) ise finansal gelişmişlik ve kurumsallık aracılığı ile sağlanabilen finansal kontrolün parasal kontrole göre daha başarılı olup büyüme oranını etkileyeceği düşünülse bile, bu durumun finansal varlıkların çeşitliliğine, ülkenin borçlanma ve talep yapısına göre farklı etki edeceğini belirtmişlerdir. Günümüzde bilinen McKinnon-Shaw hipotezinde finans büyüme ilişkisi ise finansal serbestleşmenin artması ile birlikte, finansal aracılar ve düşük faiz oranları aracılıkları sayesinde tasarruf sahipleri ve yatırımcılar fonları verimli kullanacak ve böylece hem yatırımlar hem de tasarruflar artarak ekonomik büyümeye olumlu etki edecektir şeklinde ele alınır (Molho, 1986, s.90-92). Bu yaklaşımların yanında ekonomik büyümenin de finansal gelişmeyi etkilediği, çift taraflı nedensellik, negatif ilişki veya ilişkisiz olduğuna dair literatürde birçok çalışma mevcuttur (Kar ve Pentecost, 2000; Doğan, 2002; Gökdeniz vd., 2003; Aslan ve Korap, 2006; Ekinci ve Gül, 2007). 
Finansal gelişme ve enflasyon ilişkisine bakılırsa, enflasyon olan ülkelerde genel olarak talep fazlası olduğundan üretim eksikliği sebebi ile genel olarak bu ülkelerin ithalata bağımlı ya da yüksek borca sahip oldukları gözlemlenmektedir. Bu ülkelerde ödeme riski olduğu için faiz oranları daha yüksek olmakta ve finansal gelişme de zaman zaman bu durumdan olumsuz etkilenmektedir. Azariadis ve Smith (1996), Moore (1986)'un yapmış oldukları çalışmalara göre; enflasyon oranının yüksek olması tasarrufların getirisinde azalmaya sebep olur, dolayısıyla bu da tasarrufların kendisinde azalmaya sebep olur. Bu azalış ise kredi kaynaklarının azalmasına sebep olarak, finansal sektörü olumsuz etkiler şeklinde yorumlamışlardır. Schreft ve Smith (1997), Huybens ve Smith (1998) enflasyon oranındaki yükseklik ekonomide bozulmalara yol açarak ekonomiyi denge durumundan uzaklaştırmakta ve yüksek enflasyon oranını takip eden yüksek faiz oranları sebebi ile finansal piyasaların etkinliği bu ekonomilerde azalmaktadır. Boyd vd. (1996) ise enflasyon oranı belli bir oranın üzerinde (örneğin \%40) ise bu negatif kolerasyonun daha yüksek ve güçlü olduğunu, büyümeyi de olumsuz etkilediğini belirtmektedirler. Bunun yanında finansal gelişmenin enflasyon üzerindeki etkisinin yönünü belirlemek güçtür. Finansal gelişmişlik endeksi düşük olup, enflasyon oranı düşük olan Çek Cumhuriyeti, Meksika, Slovakya gibi birçok ülke mevcuttur. Ancak finansal gelişme oranı yüksek olan ülkelerde enfasyon oranının düşük (\%4'ün altında olduğu) söylenebilir.

Finansal gelişme işsizlik oranı arasında bir ilişki kurulduğunda, muhakkak ki finansal gelişmenin işsizliğe olumlu ya da olumsuz katkısı vardır. Hem ulusal hem de uluslararası arenada yer alan finansal firmalar birçok kişiye istihdam olanağı sunmaktadır. Kaynak ihtiyacı olan girişimciler veya inovatörler finansal aracılar aracılığı ile ihtiyacı olan fonu elde ederek yeni iş alanları ve iş imkanları yaratmaktadır. Uluslararası artan finansal sermaye tüketim üretim döngüsünü gösteren çarpan etkisi ile dünya genelinde istihdamın artmasına katkıda bulunmaktadır. Suki (2006)'de Sırbistan için yapmış olduğu çalışmasında finansal sektörün gelişiminin yatırım fırsatlarını arttıracağı ve böylece istihdam olanaklarının artacağı sonucuna ulaşmıştır (Akt: Kanberoğlu, 2014, s.87). Ancak kırılgan bir yapıya ve birçok faktöre bağlı olan finans sektöründe veya reel sektörlerde görülen kriz dönemlerinde alınan ilk önlem eleman sayısında kısıtlamaya gitmektir. Bu da işsizlik oranında yükselişe sebep olmaktadır. 
Ancak işsizliğin finansal gelişme üzerinde katkısı olduğunu söylemek zordur. Çünkü finansal gelişme daha çok teknolojiye olmak üzere, gelir düzeyi, kalifiye beşeri sermaye, küreselleşme, kültür, ekonomik istikrar gibi birçok faktöre bağlıdır. Gatti vd. (2012) ise finansal piyasalar ve işsizlik ilişkisini araştırdıkları çalışmalarında, kredi piyasalarında artan rekabet ve işgücü esnekliğinin işsizliği azalttığı sonucuna ulaşmışlardır. Kanberoğlu (2014) ise Türkiye için yapmış olduğu çalışmasında işsizlik ve finansal gelişme göstergeleri arasında anlamlı bir ilişki olmadığını tespit etmiştir.

Finansal sistemde faiz önemli bir yere sahiptir. Çünkü faiz, sermayenin fiyatıdır. Tasarruf ve yatırımlar açısından likidite tercihinin önemli bir belirleyicisidir. Tabii ki yatırımcı veya borçlu için de maliyet unsurudur. Faiz oranı, enflasyon geri ödememe riski, vade gibi birçok unsura göre değişir. Bu sebeple faiz oranları ülkelerin finansal risklerinin bir göstergesi olarak sayılabilir. OECD ülkelerine bakıldığında finansal gelişmişlik endeksi yüksek ülkelerin genelinde uzun vadeli faiz (on yıllık tahvil faiz oranlarının) oranlarının düşük olduğu gözlemlenmiştir. Ancak kamu ve özel sektör borcu yüksek olan ülkelerde faiz oranları yükselmektedir. Yüksek borç yüksek faiz sarmalına giren ülkelerin bu durumunun finansal gelişmişliklerini ve likiditelerini olumsuz etkilediği düşünülmektedir.

\section{OECD ülkelerinin finansal gelişme ve ekonomik performans değer- lendirmesi}

Çalışmanın üçüncü kısmında IMF veri tabanından elde edilen finansal gelişmişlik endeksi verileri ile ülkelerin ortalamaya ve yayınlanan son veri tarihi olan 2016 yılına göre finansal gelişmişlik düzeyi sıralamaları yapılmıştır. Daha sonra bu sıralama Hanke'nin uyarladığı sefalet endeksinden faydalanarak ekonomik performans için gerçekleştirilmiştir. Hanke' nin uyarlanmış sefalet endeksi verileri IMF, OECD ve Eurostat veri tabanından elde ettiğimiz veriler ile tarafımızca hesaplanmıştır. Tablo 3 , 4,5 ve 6'da yer alan bilgilere göre ülkelerin başarı ve başarısızlık nedenlerinin değerlendirmesi yapılmıştır.

Tablo 3, OECD ülkelerinin y1llara göre finansal gelişmişlik endeksi değerlerini, Tablo 4 ise OECD ülkelerin 2006-2016 yılları ortalamasına ve 
son değer olan 2016 yılına göre, ülkelerin finansal gelişmişlik başarı sırasını vermektedir. Finansal gelişmişlik endeksi en iyi olan ülke $0.94 \mathrm{pu}-$ anla İsviçre'dir. 2007 yılında en yüksek finansal gelişmişlik endeksi puanı olan 1 tam puan seviyesini yakalamıştır. Dünyanın en büyük ve saygın bankaları İsviçre'de bulunmaktadır. Ayrıca yatırımcıları korumak adına çıkarttıkları banka gizliliği kuralları yabancı sermayeyi çekmede etkili olmuştur. Bunun yanında istikrarlı ekonomileri, düşük enflasyon ve işsizliğe sahip olmaları, alım gücü yüksek vatandaşlara sahip olmalarını sağlamıştır. İsviçre'nin finansal ürünlere ve güvenlik ağlarına yaptıkları yatırımlar ve bu alanda geliştirdikleri reformlar başarıyla sonuçlanmıştır. $\mathrm{Bu}$ anlamda Zürih dünyanın finans merkezi olarak görülmektedir (IFFC A, 2018). Finansal gelişme anlaminda ikinci en iyi ülke 0.88 puanla Avustralya'dır. Avustralya başarısını güçlü ekonomik yapısına ve güçlü temellere dayanan dengeli finans sistemine borçludur. Yabancı sermayenin yatırım tercihlerinde en önemli etkenlerden biri olan istikrarlı bir ekonomiye sahip olması ve kredi derecelendirme kuruluşlarının ülkeye yüksek notlar vermesi, ülkenin sermaye çekme oranındaki başarısını arttırmıştır, bu durumda finansal anlamda güçlenmesinde etkili olmuştur (Ticaret, 2018). İspanya ve ABD'nin ortalama 0.87 puanla üçüncü en iyi finansal gelişmişlik performansına sahip oldukları görülmektedir. İspanya'nın başkenti olan Madrid önemli finans merkezlerinden biridir. Madrid Avrupa'nın en büyük üçüncü borsası olarak görülmektedir. Bu anlamda İspanya'da güçlü bir uluslararası bankacılık yapısına ve iyi bir denetim sistemine sahiptir. Ayrıca düşük işlem maliyetleri, cazip vergi sistemleri ve sigortacılık alt yapıları, lojistik yapılanmaları İspanya'nın finansal başarısını olumlu etkilemiştir (IFFC B, 2018). ABD ise uluslararası finans merkezlerinden biri olan Newyork Borsası'na sahiptir. ABD dolarının dünya çapında kabul görmesi, dünyanın en iyi bankalarının burada kurulması, yatırımcıların genellikle uluslararası para birimi dolar üzerinden borçlanması, ABD'nin büyük ve çok uluslu şirketlere sahip olması ve bu tür yatırımcıları çekmedeki başarısı finansal başarısına yansımıştır (IFFC C, 2018).

Tablo 3 ve Tablo 4 incelendiğinde 2008 finansal krizinin ülkelerin finansal gelişmişlik endekslerinde genel olarak bir azalmaya sebep olduğu görülmektedir. Bunun yanında Avustralya, Kanada, ABD, İspanya, İngiltere finansal gelişme endeksi 0.85 ve üzerinde olan ülkelerdir. Yunanistan, 
Hollanda, Norveç, İzlanda ve Slovenya'nın finansal gelişme performanslarında son dönemde ortaya çıkan azalmalar dikkat çekmektedir. Çek Cumhuriyeti, Litvanya, Polonya, Slovakya, Letonya, Türkiye, Meksika, Slovenya finansal gelişme endeksi 0.50'nin altında olan OECD ülkeleridir. Türkiye 2016 itibariyle 34 OECD ülke içinde finansal gelişmişlik sıralamasında 25. Sırada yer almıştır. Sıralama olarak çok başarılı olmasa da, yıllara göre değerlendirildiğinde, finansal gelişmişliğini yıllar itibariyle arttırmayı başarabilmiştir. Litvanya ise bu sıralamadaki en başarısız ülkedir. Başarı sıralamalarına bakıldığında, ülkelerin gelişmişlik düzeylerinin finansal gelişmişliğine yansıdığ görülmektedir.

Tablo 3. OECD Ülkelerinin Yıllara Göre Finansal Gelişmişlik Endeksi Değerleri

\begin{tabular}{|c|c|c|c|c|c|c|c|c|c|c|c|c|}
\hline Ülkeler & ఫัస & ક્సે & ఫ్సి & ఫ్సి & 륨 & $\overrightarrow{\text { స్ }}$ & స్ & 苂 & ت্ & 록 & 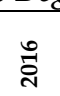 & Ortalama \\
\hline Avustralya & 0,90 & 0,95 & 0,87 & 0,88 & 0,89 & 0,90 & 0,86 & 0,84 & 0,84 & 0,86 & 0,85 & 0,88 \\
\hline Kanada & 0,81 & 0,83 & 0,84 & 0,87 & 0,83 & 0,87 & 0,86 & 0,86 & 0,87 & 0,87 & 0,86 & 0,85 \\
\hline Fransa & 0,82 & 0,82 & 0,81 & 0,76 & 0,78 & 0,79 & 0,76 & 0,75 & 0,76 & 0,76 & 0,76 & 0,78 \\
\hline İspanya & 0,91 & 0,91 & 0,86 & 0,88 & 0,86 & 0,84 & 0,82 & 0,84 & 0,89 & 0,89 & 0,88 & 0,87 \\
\hline $\mathrm{ABD}$ & 0,86 & 0,87 & 0,84 & 0,87 & 0,87 & 0,86 & 0,87 & 0,87 & 0,88 & 0,89 & 0,87 & 0,87 \\
\hline Belçika & 0,61 & 0,65 & 0,66 & 0,59 & 0,57 & 0,57 & 0,56 & 0,58 & 0,56 & 0,61 & 0,58 & 0,59 \\
\hline İrlanda & 0,78 & 0,79 & 0,79 & 0,77 & 0,75 & 0,68 & 0,71 & 0,74 & 0,71 & 0,69 & 0,69 & 0,74 \\
\hline Hollanda & 0,84 & 0,85 & 0,80 & 0,82 & 0,81 & 0,76 & 0,72 & 0,72 & 0,70 & 0,70 & 0,71 & 0,77 \\
\hline Norveç & 0,76 & 0,80 & 0,75 & 0,78 & 0,74 & 0,74 & 0,68 & 0,65 & 0,68 & 0,69 & 0,69 & 0,72 \\
\hline İngiltere & 0,90 & 0,94 & 0,88 & 0,89 & 0,84 & 0,84 & 0,82 & 0,84 & 0,84 & 0,83 & 0,82 & 0,86 \\
\hline Almanya & 0,80 & 0,79 & 0,76 & 0,77 & 0,75 & 0,73 & 0,72 & 0,70 & 0,71 & 0,73 & 0,70 & 0,74 \\
\hline İsveç & 0,80 & 0,83 & 0,75 & 0,78 & 0,76 & 0,74 & 0,73 & 0,73 & 0,72 & 0,72 & 0,72 & 0,75 \\
\hline İsviçre & 0,82 & 1,00 & 0,98 & 0,95 & 0,93 & 0,95 & 0,91 & 0,93 & 0,93 & 0,95 & 0,94 & 0,94 \\
\hline $\begin{array}{l}\text { Dani- } \\
\text { marka }\end{array}$ & 0,72 & 0,74 & 0,66 & 0,73 & 0,72 & 0,66 & 0,68 & 0,67 & 0,67 & 0,67 & 0,64 & 0,69 \\
\hline Finlandiya & 0,69 & 0,69 & 0,63 & 0,60 & 0,68 & 0,70 & 0,68 & 0,69 & 0,68 & 0,68 & 0,66 & 0,67 \\
\hline $\begin{array}{l}\text { Yeni } \\
\text { Zelanda }\end{array}$ & 0,56 & 0,55 & 0,55 & 0,57 & 0,58 & 0,59 & 0,59 & 0,57 & 0,58 & 0,57 & 0,61 & 0,57 \\
\hline Japonya & 0,84 & 0,86 & 0,82 & 0,82 & 0,83 & 0,81 & 0,81 & 0,85 & 0,85 & 0,87 & 0,87 & 0,84 \\
\hline Avusturya & 0,72 & 0,75 & 0,77 & 0,69 & 0,68 & 0,67 & 0,65 & 0,65 & 0,63 & 0,62 & 0,64 & 0,68 \\
\hline İtalya & 0,79 & 0,80 & 0,78 & 0,79 & 0,77 & 0,77 & 0,79 & 0,78 & 0,80 & 0,82 & 0,80 & 0,79 \\
\hline Portekiz & 0,72 & 0,81 & 0,74 & 0,70 & 0,71 & 0,66 & 0,65 & 0,68 & 0,73 & 0,70 & 0,69 & 0,71 \\
\hline Çek Cum. & 0,40 & 0,40 & 0,42 & 0,37 & 0,35 & 0,37 & 0,36 & 0,37 & 0,37 & 0,37 & 0,37 & 0,38 \\
\hline $\begin{array}{l}\text { Yunani- } \\
\text { stan }\end{array}$ & 0,60 & 0,63 & 0,69 & 0,64 & 0,64 & 0,63 & 0,56 & 0,59 & 0,62 & 0,56 & 0,54 & 0,61 \\
\hline Macaristan & 0,50 & 0,56 & 0,53 & 0,57 & 0,57 & 0,52 & 0,46 & 0,46 & 0,43 & 0,42 & 0,44 & 0,50 \\
\hline İzlanda & 0,85 & 0,85 & 0,71 & 0,57 & 0,53 & 0,62 & 0,59 & 0,59 & 0,56 & 0,57 & 0,54 & 0,63 \\
\hline İsrail & 0,56 & 0,58 & 0,65 & 0,62 & 0,64 & 0,62 & 0,59 & 0,58 & 0,59 & 0,61 & 0,57 & 0,60 \\
\hline Kore & 0,81 & 0,82 & 0,79 & 0,83 & 0,81 & 0,83 & 0,86 & 0,85 & 0,85 & 0,85 & 0,86 & 0,83 \\
\hline Litvanya & 0,33 & 0,33 & 0,30 & 0,29 & 0,30 & 0,27 & 0,27 & 0,26 & 0,26 & 0,26 & 0,26 & 0,28 \\
\hline
\end{tabular}




\begin{tabular}{|l|l|l|l|l|l|l|l|l|l|l|l|l|}
\hline Polonya & 0,42 & 0,46 & 0,48 & 0,46 & 0,47 & 0,49 & 0,48 & 0,48 & 0,47 & 0,47 & 0,47 & 0,47 \\
\hline Slovakya & 0,27 & 0,28 & 0,29 & 0,30 & 0,31 & 0,30 & 0,31 & 0,32 & 0,32 & 0,32 & 0,32 & 0,30 \\
\hline Letonya & 0,34 & 0,36 & 0,34 & 0,35 & 0,35 & 0,33 & 0,32 & 0,31 & 0,29 & 0,28 & 0,29 & 0,32 \\
\hline Şili & 0,48 & 0,52 & 0,51 & 0,53 & 0,51 & 0,51 & 0,50 & 0,51 & 0,50 & 0,47 & 0,47 & 0,50 \\
\hline Türkiye & 0,43 & 0,46 & 0,45 & 0,47 & 0,49 & 0,48 & 0,49 & 0,51 & 0,52 & 0,51 & 0,50 & 0,48 \\
\hline Meksika & 0,33 & 0,40 & 0,39 & 0,38 & 0,40 & 0,39 & 0,40 & 0,42 & 0,38 & 0,39 & 0,41 & 0,39 \\
\hline Slovenya & 0,54 & 0,57 & 0,53 & 0,58 & 0,54 & 0,50 & 0,49 & 0,46 & 0,42 & 0,39 & 0,39 & 0,49 \\
\hline
\end{tabular}

Tablo 4. OECD Ülkelerinin Finansal Gelişmişlik Sıralamaları

\begin{tabular}{|l|l|l|l|l|l|}
\hline Sira No & Ortalama & $\mathbf{2 0 1 6}$ & Sira No & Ortalama & $\mathbf{2 0 1 6}$ \\
\hline 1 & İsviçre & İsviçre & 18 & Avusturya & Danimarka \\
\hline 2 & Avustralya & İspanya & 19 & Finlandiya & Avusturya \\
\hline 3 & İspanya & ABD & 20 & İzlanda & Yeni Zellanda \\
\hline 4 & ABD & Japonya & 21 & Yunanistan & Belçika \\
\hline 5 & İngiltere & Kanada & 22 & İsrail & İsrail \\
\hline 6 & Kanada & Kore & 23 & Belçika & İzlanda \\
\hline 7 & Japonya & Avustralya & 24 & Yeni Zelanda & Yunanistan \\
\hline 8 & Kore & İngiltere & 25 & Şili & Türkiye \\
\hline 9 & İtalya & İtalya & 26 & Macaristan & Şili \\
\hline 10 & Fransa & Fransa & 27 & Slovenya & Polonya \\
\hline 11 & Hollanda & İsveç & 28 & Türkiye & Macaristan \\
\hline 12 & İsveç & Hollanda & 29 & Polonya & Meksika \\
\hline 13 & Almanya & Almanya & 30 & Meksika & Slovenya \\
\hline 14 & İrlanda & İlanda & 31 & Çek Cum. & Çek Cum. \\
\hline 15 & Norveç & Norveç & 32 & Letonya & Slovakya \\
\hline 16 & Portekiz & Portekiz & 33 & Slovakya & Letonya \\
\hline 17 & Danimarka & Finlandiya & 34 & Litvanya & Litvanya \\
\hline
\end{tabular}

Tablo 5'de verilen Hanke'nin uyarlanmış performans endeksine göre endeks notunun azalması ekonomik performansın iyileşmesi anlamına gelmektedir. 34 OECD ülkesinin ekonomik performansına bakıldığında Avustralya, Kanada, Fransa, ABD, Hollanda, Norveç, İsviçre, İsveç, Japonya, Avusturya, Çek Cumhuriyeti, Kore gibi ülkelerin endeks değerleri daha istikrarlıdır.

İsviçre'nin 11 yıllık bu sürecin 9 yılında birinci veya ikinci sırada en başarılı ülke olarak yer alması dikkat çekmektedir. İsviçre'nin finansal gelişmişlik performans olarak da en başarılı ülke olması, finansal gelişmişlik ve ekonomik performansın pozitif ilişkisinin önemli örneklerinden biri olarak gösterilebilir. İsviçre gelişmiş ülke kategorisinde yer alması sebebiyle düşük, zaman zaman da negatif büyüme oranlarına sahiptir. İsviçre'de fiyatlar genel düzeyi sıfıra yakın olmakla birlikte, genellikle paranın satın alma gücü artmaktadır. Bu ekonomideki arz 
fazlasından kaynaklanmaktadır. İşsizlik oranı da \%3-4 arasında oldukça düşük değerlerdedir. Ülke riskini gösteren uzun dönem faiz oranı da \%3' ün altında, son dönemde sıfıra yakındır. İsviçre'nin hem finansal hem de ekonomik performans anlamında diğer ülkelerden daha fazla başarılı olmasının nedenleri Katzenstein'in (1980) "Capitalism in one Country? Switzerland in the International Economy" adlı çalışmasından faydalanılarak açıklanmıştır. İsviçre bu başarısını para politikasını yönetmedeki başarısına ve sanayi ürünleri ihracatına bakış açısına borçludur. Ülke küçük olsa da uluslararası pazarlar büyüktür felsefesi ile hareket edilmektedir. Uluslararası serbestleşme, değişime uyum, özel girişimlere bağlı yurtiçi istikrar olmak üzere üç önemli stratejiye sahiptirler. İsviçre dünyanın en düşük gümrük tarifesine sahiptir, bu da ihracatın artmasında önemli rol oynamıştır. İthalat kısıtlamaları yerine ihracat teşvikleri uygulanmaktadır. İhracat sigortası kur ve satış riskini azalttığı için firmalar üretimlerini rahatlıkla arttırabilmiş, çokuluslu firmaların ve KOBİlerin büyümesi sağlanmıştır. Tek taraflı barış sözleşmesi, ülkenin savaş riskini minumuma indirmiştir. Bunun yanında banka ve hesap bilgilerinin gizliliği konusundaki başarısı yatırımları çekmede etkili olmuştur. Finansal anlamdaki gücü doğal olarak ekonomik göstergelerine yansımıştır. Büyük bankaları ve Merkez bankası birlikte hareket etmektedir ve kriz dönemlerinde büyük bankalar fonlama kısmında ülkeye destek olduğu için ülke istikrarı bozulmamaktadır. İhracat teşviklerinin 3/5'ini özel bankalar karşılamaktadır. Bu da ülkede her bir firmanın bir bütün olarak hareket ettiğinin ayrı bir göstergesidir. Bu sayede ülkede oluşan istikrar, portföy yatırımlarını çekmede etkili olmaktadır. Ülke Ar-Ge faaliyetlerine önem vermektedir, Ar-Ge ilk yıllarda devlet sponsorluğunda yapılmış, daha sonra Ar-Ge harcamalarının \%80'i özel firmalar tarafından gerçekleştirilmiştir. Devletin ekonomideki rolü sınırlıdır. Bireysel tasarruf oranı ve sigorta fonları oldukça yüksek olduğu için vergi kesintileri yapılabilmiştir. Bankalar bağımsızdır, siyasi otoriteye göre uygulamalar yapmazlar. İsviçre'nin politik yapısının en temel özellikleri ise; sosyal demokrasi, yüksek derecede fikir birliği ve politika sürekliliğidir. Önemli bir yasa değişikliği durumunda referandum yolu tercih edilir. Kuvvetler ayrılığı ilkesi geçerlidir. Tarafsızlık ve evrensellik dış politika stratejilerinin temelini oluşturmaktadır. Özetle; İsviçre'nin savaşa karşı tarafsız duruşu, finansal gizlilik anlayışı, sahip olduğu istikrar ve ihracat sigorta 
fonları onu ekonomik performans anlamında diğer ülkelerden daha başarılı kılmıştır.

Japonya ise ekonomik performans anlamında yine ilk üçte yer alan ülkelerden biri olmuştur. Bu ülke gücünü, istikrarlı siyasi iktidarın, büyük şirketlerin ve güçlü bürokrasinin işbirliği içinde çalışmasından almıştır. Büyük şirket gruplarına finansal kolaylıklar sağlanmış ve bu şirketlerde çalışanlara ömür boyu iş garantisi verilmiştir (Ateş, 2003, s.5). Gelişmiş ülke kategorisinde yer alan Japonya'nın da ekonomik büyüme kategorisinde çok başarılı olduğu söylenemez. 2006-2016 yılları arasında daralmalar yaşamış ve 2010 dışında büyüme oranı \%2'yi aşmamıştır. Japonya paranın değerini korumayı başaran ülkelerden biridir ve enflasyon problemi yoktur. İşsizlik oranı da \%3-5 arasında gerçekleşmektedir. Faiz oranı sıfıra yakın olan ülkelerden biri de Japonya'dır. Japon ekonomisindeki ömürboyu işgarantisi sistemi, şirketin çalışanlarını geliştirmek için programlar hazırlamasını, uzun vadeli büyüme stratejileri geliştirmesini, işçilerin de kendilerini güvende hissetmelerini sağlamıştır. Bunun yanında şirket içinden yükselme ile çalışanların verimliliği ve rekabeti artmıştır. İş rotasyonu da yöneticilerin yapılan iş hakkında yerinde bilgi edinmesini olanaklı kılmıştır. Bu yönetim ve iş anlayışı, kurumsallaşmaya verilen önem Japonya'daki şirketlerin hızla büyümesini ve uluslararası piyasada söz sahibi olmasını beraberinde getirmiştir (Sı̆̆rı, 2006, s.29-47).

İspanya ise finansal gelişmişlik performansı olarak yakaladığı başarıyı temel ekonomik göstergelerde yakalayamamıştır. Çünkü İspanya'nın talep yapısı borca dayalı tüketim anlayışına sahiptir. 2008 krizinde yaşanan daralmadan çıktığını söylemek halen güçtür. İspanya petrol fiyatlarındaki düşüşten faydalanmıştır ve ciddi bir enflasyon problemi olduğu söylenemez. Ancak kamu kesimi açı̆̆ına sahiptir. Hem özel sektörün hem de kamu kesiminin borcu yüksektir. Bu açı̆̆ kapatmak için ödenen faizlerde ülke ekonomisi üzerinde mali bir yüktür. Bu açıkları kapatmak için uygulanan kemer sıkma politikaları işsizliğin daha da artmasına sebep olmuştur. 2016 itibariyle her beş kişiden biri işsizdir. Euro para birimine geçmeleri faiz oranlarındaki düşüşün sebebidir (Ticaret Bakanlı̆̆1, 2018). 
Tablo 5. Hanke'nin Uyarlanmış Sefalet Endeksine Göre Ülkelerin Ekonomik Performanslart

\begin{tabular}{|c|c|c|c|c|c|c|c|c|c|c|c|}
\hline Ülkeler & 2006 & 2007 & 2008 & 2009 & 2010 & 2011 & 2012 & 2013 & 2014 & 2015 & 2016 \\
\hline Avustralya & 11,09 & 8,92 & 10,74 & 10,80 & 11,44 & 10,81 & 6,47 & 9,17 & 9,66 & 7,93 & 6,51 \\
\hline Kanada & 9,91 & 10,39 & 11,11 & 14,82 & 9,99 & 10,06 & 8,93 & 7,80 & 8,19 & 8,56 & 8,27 \\
\hline Fransa & 11,55 & 11,09 & 13,91 & 15,42 & 11,55 & 12,16 & 13,71 & 12,41 & 11,53 & 10,17 & 9,52 \\
\hline İspanya & 10,40 & 11,59 & 20,05 & 25,25 & 27,35 & 30,60 & 37,74 & 33,83 & 29,30 & 19,38 & 14,66 \\
\hline $\mathrm{ABD}$ & 9,97 & 10,32 & 13,58 & 14,93 & 11,95 & 13,29 & 9,72 & 9,52 & 7,76 & 4,67 & 6,49 \\
\hline Belçika & 11,35 & 10,16 & 15,10 & 14,01 & 11,20 & 13,11 & 13,14 & 11,75 & 9,28 & 8,45 & 8,87 \\
\hline İrlanda & 6,61 & 8,69 & 18,95 & 17,39 & 17,12 & 23,77 & 22,32 & 15,74 & 5,38 & $-15,33$ & 3,44 \\
\hline Hollanda & 5,26 & 5,38 & 7,76 & 12,05 & 7,31 & 8,65 & 11,27 & 11,90 & 8,43 & 5,90 & 4,41 \\
\hline Norveç & 8,10 & 4,99 & 10,28 & 10,99 & 8,78 & 6,66 & 3,20 & 7,07 & 6,06 & 6,07 & 8,47 \\
\hline İngiltere & 9,74 & 10,33 & 14,28 & 17,56 & 13,02 & 14,19 & 11,13 & 10,44 & 7,10 & 4,91 & 4,82 \\
\hline Almanya & 11,89 & 11,91 & 13,05 & 16,89 & 6,74 & 6,84 & 8,39 & 7,82 & 5,12 & 3,61 & 3,56 \\
\hline İsveç & 7,43 & 9,09 & 14,06 & 16,24 & 6,64 & 10,67 & 10,73 & 8,85 & 6,86 & 3,55 & 5,26 \\
\hline İsviçre & 3,59 & 3,20 & 6,52 & 8,06 & 4,13 & 4,42 & 3,43 & 3,63 & 3,06 & 3,12 & 3,47 \\
\hline Danimarka & 5,72 & 8,87 & 11,64 & 15,81 & 10,83 & 11,72 & 11,10 & 8,60 & 6,86 & 5,71 & 4,79 \\
\hline Finlandiya & 9,01 & 8,47 & 14,01 & 20,26 & 9,69 & 12,21 & 13,81 & 12,29 & 11,78 & 9,76 & 7,41 \\
\hline Yeni Zelanda & 10,42 & 8,48 & 16,33 & 11,48 & 13,08 & 12,25 & 8,66 & 9,81 & 7,37 & 4,65 & 5,05 \\
\hline Japonya & 4,70 & 3,92 & 7,92 & 10,48 & 1,31 & 5,50 & 3,64 & 3,07 & 6,49 & 3,12 & 2,74 \\
\hline Avusturya & 7,03 & 7,60 & 10,24 & 13,51 & 8,02 & 8,24 & 9,05 & 9,40 & 7,88 & 6,27 & 5,83 \\
\hline İtalya & 11,33 & 10,92 & 15,80 & 18,32 & 12,56 & 15,99 & 22,00 & 19,41 & 15,70 & 12,70 & 12,22 \\
\hline Portekiz & 13,12 & 12,35 & 14,46 & 15,78 & 15,67 & 28,40 & 32,88 & 23,88 & 16,47 & 13,53 & 13,23 \\
\hline Çek Cum. & 6,63 & 6,87 & 12,70 & 17,32 & 10,36 & 10,56 & 13,85 & 10,98 & 5,31 & 0,63 & 2,47 \\
\hline Yunanistan & 11,25 & 12,52 & 17,05 & 20,30 & 32,82 & 46,07 & 55,74 & 40,33 & 31,37 & 33,12 & 31,32 \\
\hline Macaristan & 14,68 & 21,68 & 21,25 & 29,97 & 22,62 & 20,93 & 26,19 & 15,74 & 8,08 & 6,81 & 6,43 \\
\hline İzlanda & 13,33 & 7,29 & 25,67 & 33,98 & 23,42 & 15,05 & 16,06 & 10,73 & 11,12 & 7,56 & 2,80 \\
\hline İsrail & 13,92 & 9,65 & 15,23 & 17,11 & 10,63 & 10,92 & 11,02 & 7,44 & 5,84 & 4,31 & 2,04 \\
\hline Kore & 5,67 & 5,65 & 10,57 & 10,86 & 4,94 & 7,96 & 6,56 & 4,80 & 4,65 & 3,85 & 3,50 \\
\hline Litvanya & 6,92 & 3,45 & 19,74 & 47,47 & 23,06 & 18,64 & 17,45 & 13,15 & 10,06 & 7,58 & 7,32 \\
\hline Polonya & 14,18 & 10,51 & 13,75 & 15,27 & 14,40 & 14,81 & 17,04 & 14,26 & 9,28 & 5,48 & 5,99 \\
\hline Slovakya & 13,81 & 7,59 & 13,20 & 23,77 & 14,17 & 19,14 & 20,46 & 17,32 & 13,06 & 8,19 & 6,37 \\
\hline Letonya & 5,81 & 11,45 & 33,12 & 47,80 & 32,67 & 20,11 & 17,84 & 12,75 & 12,12 & 8,04 & 8,11 \\
\hline Şili & 10,92 & 13,52 & 20,09 & 17,27 & 10,24 & 10,54 & 9,77 & 9,40 & 14,02 & 13,03 & 13,67 \\
\hline Türkiye & 27,40 & 29,41 & 38,24 & 36,45 & 20,36 & 13,44 & 20,72 & 15,50 & 22,75 & 21,12 & 25,62 \\
\hline Meksika & 11,09 & 13,12 & 16,19 & 23,93 & 11,27 & 11,60 & 10,99 & 13,07 & 12,15 & 9,72 & 9,98 \\
\hline Slovenya & 5,32 & 9,71 & 22,42 & 9,84 & 12,22 & 17,61 & 18,38 & 14,70 & 10,88 & 6,99 & 4,09 \\
\hline
\end{tabular}

Ekonomik performansta en başarısız ülkeler İspanya dışında, Yunanistan ve Türkiye'dir. Finansal gelişme endeksi anlamında Yunanistan Türkiye'ye göre daha başarılı iken, büyüme performansı bakımından Türkiye Yunanistan'a fark atmaktadır. 2008 yılından itibaren 2014 dışında Yunanistan ekonomisi hep negatif büyüme oranına sahiptir, ekonomide küçülme yaşanmıştır. Türkiye ise 2009 yılı dışında hep pozitif büyümüş ve bu oranın \%11'lere ulaştığı olmuştur. Ancak yüksek büyümeye bağlı enflasyon problemi Türkiye'nin performansını düşürmüştür. Son dönemde Yunanistan'ın işsizlik oranı Türkiye'nin iki katından fazladır. 2009'a kadar Türkiye'de uzun dönem faiz oranı daha yüksekken, 2009 
sonrası tam tersi oldu ve 2012 yılında Yunanistan'da faiz oranı \%22 gibi oldukça yüksek bir rakama ulaştı. Son dönemlerde ise bu oran iki ülke için de \%8-9 civarındadır.

Tablo 6. Hanke'nin Uyarlanmış Sefalet Endeksine Göre Ülkelerin Ekonomik Performans Siralamaları

\begin{tabular}{|c|c|c|c|c|c|c|c|c|c|c|c|}
\hline Ülkeler & 2006 & 2007 & 2008 & 2009 & 2010 & 2011 & 2012 & 2013 & 2014 & 2015 & 2016 \\
\hline Avustralya & 21 & 15 & 7 & 4 & 17 & 12 & 4 & 10 & 20 & 21 & 20 \\
\hline Kanada & 16 & 22 & 8 & 11 & 10 & 8 & 8 & 6 & 16 & 25 & 24 \\
\hline Fransa & 26 & 25 & 15 & 14 & 18 & 16 & 19 & 21 & 24 & 28 & 27 \\
\hline İspanya & 18 & 27 & 28 & 29 & 32 & 33 & 33 & 33 & 33 & 32 & 32 \\
\hline $\mathrm{ABD}$ & 17 & 20 & 13 & 12 & 19 & 20 & 10 & 13 & 13 & 10 & 19 \\
\hline Belçika & 25 & 19 & 20 & 10 & 15 & 19 & 18 & 18 & 19 & 24 & 26 \\
\hline İrlanda & 8 & 13 & 26 & 22 & 27 & 31 & 30 & 28 & 5 & 1 & 5 \\
\hline Hollanda & 3 & 5 & 2 & 8 & 6 & 7 & 17 & 19 & 17 & 14 & 10 \\
\hline Norveç & 13 & 4 & 5 & 6 & 8 & 3 & 1 & 4 & 7 & 15 & 25 \\
\hline İngiltere & 15 & 21 & 18 & 23 & 22 & 22 & 16 & 15 & 11 & 11 & 12 \\
\hline Almanya & 27 & 28 & 11 & 18 & 5 & 4 & 6 & 7 & 3 & 6 & 8 \\
\hline İsveç & 12 & 16 & 17 & 17 & 4 & 11 & 12 & 9 & 9 & 5 & 14 \\
\hline İsviçre & 1 & 1 & 1 & 1 & 2 & 1 & 2 & 2 & 1 & 4 & 6 \\
\hline Danimarka & 6 & 14 & 9 & 16 & 14 & 15 & 15 & 8 & 10 & 13 & 11 \\
\hline Finlandiya & 14 & 11 & 16 & 25 & 9 & 17 & 20 & 20 & 25 & 27 & 22 \\
\hline Yeni Zelanda & 19 & 12 & 24 & 7 & 23 & 18 & 7 & 14 & 12 & 9 & 13 \\
\hline Japonya & 2 & 3 & 3 & 3 & 1 & 2 & 3 & 1 & 8 & 3 & 3 \\
\hline Avusturya & 11 & 10 & 4 & 9 & 7 & 6 & 9 & 12 & 14 & 16 & 15 \\
\hline İtalya & 24 & 24 & 22 & 24 & 21 & 25 & 29 & 31 & 30 & 29 & 29 \\
\hline Portekiz & 28 & 29 & 19 & 15 & 26 & 32 & 32 & 32 & 31 & 31 & 30 \\
\hline Çek Cum. & 9 & 7 & 10 & 21 & 12 & 10 & 21 & 17 & 4 & 2 & 2 \\
\hline Yunanistan & 23 & 30 & 25 & 26 & 34 & 34 & 34 & 34 & 34 & 34 & 34 \\
\hline Macaristan & 33 & 33 & 30 & 30 & 29 & 30 & 31 & 29 & 15 & 17 & 18 \\
\hline İzlanda & 29 & 8 & 32 & 31 & 31 & 24 & 22 & 16 & 23 & 19 & 4 \\
\hline İsrail & 31 & 17 & 21 & 19 & 13 & 13 & 14 & 5 & 6 & 8 & 1 \\
\hline Kore & 5 & 6 & 6 & 5 & 3 & 5 & 5 & 3 & 2 & 7 & 7 \\
\hline Litvanya & 10 & 2 & 27 & 33 & 30 & 27 & 24 & 24 & 21 & 20 & 21 \\
\hline Polonya & 32 & 23 & 14 & 13 & 25 & 23 & 23 & 25 & 18 & 12 & 16 \\
\hline Slovakya & 30 & 9 & 12 & 27 & 24 & 28 & 27 & 30 & 28 & 23 & 17 \\
\hline Letonya & 7 & 26 & 33 & 34 & 33 & 29 & 25 & 22 & 26 & 22 & 23 \\
\hline Şili & 20 & 32 & 29 & 20 & 11 & 9 & 11 & 11 & 29 & 30 & 31 \\
\hline Türkiye & 34 & 34 & 34 & 32 & 28 & 21 & 28 & 27 & 32 & 33 & 33 \\
\hline Meksika & 22 & 31 & 23 & 28 & 16 & 14 & 13 & 23 & 27 & 26 & 28 \\
\hline Slovenya & 4 & 18 & 31 & 2 & 20 & 26 & 26 & 26 & 22 & 18 & 9 \\
\hline
\end{tabular}

İspanya, Türkiye ve Yunanistan'ın OECD ülkeleri arasında en kötü performanslara sahip olmalarının nedeni OECD'ye üye ülkelerin genellikle gelişmiş ülke kategorisinde yer alması ve bu ülkelerin ortalama işsizlik ve enflasyon oranlarının çok üstünde rakamlara sahip olmalarıdır. Yunanistan ekonomisinin yüksek bütçe açığı ve kamu borçlarının yüksekliği, 
ekonomi yönetimini zorlaştırmaktadır. Türkiye'de yüksek kamu borçları, ithalata dayalı ihracat, borçlanmaya dayalı tüketim anlayışı gibi kronik problemlerden dolayı ekonomideki enflasyon ve işsizlik probleminin kalıcı çözümünü hala geliştirememiştir.

\section{Veri seti, yöntem ve ampirik sonuçlar}

Çalışma kapsamında finansal gelişme ve ekonomik performans arasındaki ilişkinin varlığını tespit etmek amacıyla finansal gelişme endeksi (fge) ve ekonomik performans endeksi (hse) verileri kullanılmıştır. Finansal gelişmeyi temsilen finansal gelişme endeksi verileri IMF veri tabanından elde edilmiştir. Finansal gelişme endeksi verileri en güncel 2016 yılına kadar yayınladığı için çalışmada ele alınan zaman 2016 yılında sonlandırılmıştır. Tarafımızdan oluşturulan ekonomik performans endeksi (Hanke uyarlanmış sefalet endeksi) verilerinden büyüme, işsizlik ve enflasyon oranları Dünya Bankası veri tabanından, uzun dönemli faiz oranını temsilen 10 yıllık tahvil faiz oranları OECD veri tabanından, sadece Türkiye'nin faiz oranı verileri Eurostat veri tabanından elde edilmiştir. OECD ülkelerinden Estonya ve Lüksemburg ülkelerinin 10 yıllık tahvil faiz oranı yayınlanmadığı için bu ülkelerin ekonomik performans endeksleri hesaplanamamıştır. Bu sebeple çalışma kapsamında Avustralya, Avusturya, Belçika, Kanada, Şili, Çek Cumhuriyeti, Danimarka, Finlandiya, Fransa, Almanya, Yunanistan, Macaristan, İzlanda, İrlanda, İsrail, İtalya, Japonya, Kore, Letonya, Litvanya, Meksika, Hollanda, Yeni Zelanda, Norveç, Polonya, Portekiz, Slovakya, Slovenya İspanya, İsveç, İsviçre, Türkiye, İngiltere ve ABD olmak üzere 34 OECD ülkesi ele alınmıştır. Ekonomik performans hesaplamasında kullanılan 10 yıllık tahvil faiz oranları Türkiye için 2006 yılından itibaren yayınlanmaktadır. Bu sebeple OECD ülkeleri içindeki en fazla ülkeyi ele alabilmek adına çalışmanın başlangıç yılı 2006 olarak seçilerek 2006-2016 yılları için panel veri seti oluşturulmuştur. Çalışmayı uzatmamak adına uygulanan ekonometrik yöntemin, ekonometrik model açıklamalarına yer verilmeyip, ilgili kaynaklara atıf yapılmıştır.

OECD ülkeleri için 2006-2016 yılları arasında finansal gelişme ve ekonomik performans arasında uzun dönemli ilişkiyi araştırmak amacıyla 
yapısal kırılmaları dikkate alan Westerlund Eşbütünleşme analizi yöntemi uygulanmıştır. Bunun için öncelikle serilerin durağanlığının tespiti için yapılacak olan uygun birim kök testini seçebilmek adına seriler arasındaki yatay kesit bağımlılığ Tablo 7'de görüldüğü üzere her bir seri için Breusch Pagan LM testi (1980) ve Friedman testi (1937) ile sınanmıştır. Breusch Pagan LM (1980) testinde "birimler arasında kolerasyon yoktur" temel hipotezi sinanmaktadır ve LM test istatistiği $\chi^{2}$ dağglımına göre değerlendirilmektedir(Yerdelen Tatoğlu, 2013a, s.215). Friedman (1937) testi, Spearman'ın rank kolerasyon katsayısının kullanıldığı, paremetrik olmayan ve $\chi^{2}$ dağılımına göre değerlendirilen birimler arası kolerasyonun varlığını tespit etmek amacıyla kullanılan bir diğer testtir (Yerdelen Tatoğlu, 2013a, s.218). Buna göre Tablo 7'de hem Breusch Pagan LM testi (1980) ve Friedman testi (1937)'ne göre, her iki serinin de "birimler arasında kolerasyon yoktur" hipotezi, olasılık değeri \%1 değerinden küçük olduğu için reddedilmektedir ve bu sebeple birimler arasında yatay kesit bağımlılığı mevcuttur.

Tablo 7. Yatay Kesit Bă̆ımlılı̆̆ı Testi

\begin{tabular}{llll}
\hline Değişkenler & Test & Test İstatistiği & Olasılık Değeri \\
\hline fge & Breusch Pagan LM & 1566.41 & $(0.0000)$ \\
hse & Breusch Pagan LM & 264.80 & $(0.0000)$ \\
fge & Friedman & 41.508 & $(0.0000)$ \\
hse & Friedman & 176.433 & $(0.0000)$ \\
\hline
\end{tabular}

Serilerde yatay kesit bağımlılığının bulunduğu durumlarda, serilerin durağanlığının araştırılmasına imkan veren ikinci nesil birim kök tetlerinin uygulanması daha etkin sonuçlar vermektedir (Bozkurt ve Balmumcu, 2018, s.399). Peseran (2007) tarafından geliştirilen CADF(Yatay Kesit Genelleştirilmiş Dickey Fuller) Panel Birim Kök Testi yatay kesit bağımlılığını dikkate almaktadır ve ADF regresyonunun yatay kesit ortalamaları ile genişletilmiş hali kullanılmaktadır. Bu regresyonunun farkı alındığında birimler arası korelasyon problemi giderilebilmektedir (Yerdelen Tatoğlu, 2013b, s.223). Tablo 8'de gösterilen CADF test istatistiği sonuçlarına göre, \%5 anlamlılık düzeyinde üzere hem fge serisinin hem de hse serisinin düzeyde durağan oldukları sonucuna ulaşılmıştır. 
Tablo 8. CADF Panel Birim Kök Testi

\begin{tabular}{cll}
\hline Değişkenler & Z[t-bar] & Olasılık Değeri \\
\hline fge & -6.609 & 0.000 \\
hse & -2.275 & 0.011 \\
\hline
\end{tabular}

Finansal gelişme ve ekonomik performans arasındaki uzun dönemli ilişkinin sistemdeki kalıcı şoklara rağmen var olup olmadığı panel veri analizlerinden biri olan yapısal kırılmaları da dikkate alan Westerlund Panel Eşbütünleşme Testi yardımı ile incelenmiştir. Westerlund (2007), panel eşbütünleşme test istatistiklerinin eksiklerini gidermek için hata düzeltme denklemine dayalı dört temel istatistik geliştirmiştir (Göktaş, Pekmezci ve Bozkurt, 2018, s.173). Panel varyans oranı istatistiklerinde her bir birim için otoregresif parametre sabitken, grup ortalaması varyans oranı istatistiklerinde otoregresif parametre birimden birime değişmektedir. Dört temel istatistiğinde temel hipotezi, "birimlerde eşbütünleşme yoktur" şeklinde kurulmaktadır.

Tablo 9'da finansal gelişme endeksinin bağımlı değişken olduğu durumda, Tablo 10' da ise Hanke sefalet endeksinin bağımlı değişken olduğu durumda olmak üzere iki ayrı Westerlund Eşbütünleşme analizi gerçekleştirilmiştir. Yapılan analiz sonucunda Tablo 9'da da görüldüğü üzere, "eşbütünleşme ilişkisi yoktur" şeklindeki $H_{0}$ hipotezi, $G_{a}$ ve $P_{t}$ istatistikleri dışında reddedilmiştir. Bu sonuç bütün yatay kesit birimleri için finansal gelişme ve ekonomik performansın bir göstergesi olan Hanke sefalet endeksi arasında eşbütünleşme ilişkisinin olduğunu göstermektedir. Buna göre ekonomik performans finansal gelişmeyi uzun dönemde etkilemektedir.

Tablo 9. Finansal Gelişme Endeksi ve Hanke Sefalet Endeksi (Düzey Değerleri) İçin Westerlund Panel Eşbütünleşme Testi Sonuçlarn

\begin{tabular}{lccc}
\hline Test İstatistiği & Değer & z-Değeri & Olasılık Değeri \\
\hline $\mathrm{Gt}_{\mathrm{t}}$ (Gruplar Ortalaması) & -6.207 & -28.952 & 0.000 \\
$\mathrm{Ga}_{a}($ Gruplar Ortalaması) & -5.528 & 1.800 & 0.964 \\
$\mathrm{Pt}$ (Panel Ortalaması) & -9.970 & -1.354 & 0.088 \\
$\mathrm{~Pa}_{\mathrm{a}}$ (Panel Ortalaması) & -5.808 & -1.845 & 0.033 \\
\hline
\end{tabular}

Tablo 10'a göre de Hanke Sefalet Endeksi bağımlı değişken olarak kullanıldığında $\mathrm{Ga}$ istatistiği dışında diğer tüm istatistikler için 
eşbütünleşme ilişkisinin varlığı sonucuna ulaşılmıştır. Bu durumda da finansal gelişmişliğin uzun dönemde ekonomik performansı etkilediği söylenebilir.

Tablo 10. Hanke Sefalet Endeksi ve Finansal Gelişme Endeksi (Düzey Değerleri) İçin Westerlund Panel Eşbütünleşme Testi Sonuçları

\begin{tabular}{lccc}
\hline Test İstatistiği & Değer & z-Değeri & Olasılık Değeri \\
\hline Gt (Gruplar Ortalamas1) & -5.414 & -23.746 & 0.000 \\
Ga(Gruplar Ortalaması) & -4.449 & 2.962 & 0.999 \\
$\mathrm{Pt}_{\mathrm{t}}$ (Panel Ortalaması) & -15.869 & -7.177 & 0.000 \\
$\mathrm{~Pa}_{\mathrm{a}}$ (Panel Ortalamas1) & -9.484 & -6.517 & 0.000 \\
\hline
\end{tabular}

Eşbütünleşme analizlerinin ikinci aşamasında hata düzeltme mekanizmasının çalışıp çalışmadığı kontrol edilmektedir. Hata düzeltme mekanizmasının çalışması için hata teriminin negatif ve anlamlı sonuç vermesi gereklidir. Bu katsayı kısa dönemde meydana gelen dengesizliklerin ne kadar sürede uzun dönem dengesine yaklaşacağını göstermektedir. Bu çalışmada hata düzeltme mekanizmasının çalışıp çalışmadığını kontrol etmek amaciyla, hata düzeltme modeli Dinamik Sabit Etkiler Tahmincisi (DFE) ile tahmin edilmiştir. Dinamik Sabit Etkiler Tahmincisi, hata düzeltme modelini sabit etkiler varsayımı altında tahmin ederek hesaplamalar yapar. Hata düzeltme terimi anlamlı ve negatif ise iki değişken arsında uzun dönemli bir ilişki mevcuttur(Yerdelen Tatoğlu, 2013b, s.244).

Tablo 11, finansal gelişme endeksi bağımlı değişken iken panel hata düzeltme modelinin dinamik sabit etkiler tahmincisi (DFE) ile tahminini göstermektedir. Hata düzeltme parametresi (et-1) negatiftir ve anlamlıdır. Dolayısıyla iki değişken arasında ise uzun dönemli bir ilişki vardır. Buna göre bir dönemde oluşan dengesizliklerin \%35'i bir sonraki dönemde düzelerek uzun dönem dengesine yaklaşacaktır. Bunun yanında Hanke sefalet endeksi katsayısının negatif çıkması öngörülen bir sonuçtur. Çünkü ekonomik sefaletin artması, ekonomik performansın azalması olarak yorumlanır, bunun da finansal gelişmeyi negatif etkilemesi beklenmektedir. Fakat hem kısa hem de uzun dönem sefalet endeksi katsayısı anlamsız çıkmıştır. Bu durumda OECD ülkeleri için ekonomik performansın finansal gelişme üzerindeki kısa ve uzun dönem etkilerinin yönü belirsizdir. 
Tablo 11. Dinamik Sabit Etkiler Tahmini (DFE) (Bă̆ımlı değişken fge iken)

\begin{tabular}{lllll}
\hline $\begin{array}{l}\text { Bağımsız Değişken- } \\
\text { ler }\end{array}$ & Katsayı & Standart Hata & z-Değeri & Olasılık Değeri \\
\hline hse & -0.0008526 & 0.0008404 & -1.01 & 0.310 \\
hset-1 & -0.0003513 & 0.0003225 & -1.09 & 0.276 \\
et-1 & -0.3504504 & 0.0414749 & -8.45 & 0.000 \\
sabit & 0.2289469 & 0.0271537 & 8.43 & 0.000 \\
\hline
\end{tabular}

Tablo 12'de bağımlı değişkenin Hanke sefalet endeksi olduğu durumda panel hata düzeltme modelinin dinamik sabit etkiler tahmincisi(DFE) ile tahmini görülmektedir. Hata düzeltme parametresi (et-1) negitiftir ve anlamlıdır. Kısa dönemde meydana gelen dengesizlik bir sonraki dönem \%40 oranında düzelecektir. İki değişken arasında kısa dönemde negatif bir ilişki varken, uzun dönemde pozitif bir ilişki mevcuttur. Kısa dönemde finansal gelişmişlikte meydana gelen \%1'lik artış ekonomik sefaleti \%43 azaltacaktır, yani ekonomik performans artacaktır. Ancak finansal gelişme uzun dönemde ekonomik sefaleti \%54 arttırmaktadır. Finansal gelişmişlik kısa dönemde fon sağlayarak üretim ve tüketim sektörlerini olumlu etkilemektedir. Ancak bu fonlar reel üretime dönüştürülmediği sürece sadece finansal performans aracılığ 1 ile ekonomik göstergelerde olumlu değişimler beklemenin gerçekçi olmadığı düşünülmektedir.

Tablo 12. Dinamik Sabit Etkiler Tahmini (DFE) (Bağımlı değişken hse iken)

\begin{tabular}{lllll}
\hline $\begin{array}{l}\text { Bağımsız Değişken- } \\
\text { ler }\end{array}$ & Katsayı & Standart Hata & z-Değeri & $\begin{array}{l}\text { Olasılık } \\
\text { Değeri }\end{array}$ \\
\hline fge & 57.5291 & 21.07459 & 2.73 & 0.006 \\
fget-1 & -43.62924 & 9.507834 & -4.59 & 0.000 \\
et-1 & -0.4073795 & 0.0456432 & -8.93 & 0.000 \\
sabit & -10.26297 & 5.284672 & -1.94 & 0.052 \\
\hline
\end{tabular}

\section{Sonuç}

Bu çalışmada finansal gelişmişlik ve ekonomik performansın uzun dönemli ilişkisi 2006-2016 zaman aralığında OECD ülkeleri için araştırılmıştır. Finansal gelişmişliği yüksek olan ülkelerin ekonomik performans açısından daha başarılı olduğu söylenebilir. OECD ülkeleri içerisinde İsviçre ve Japonya'nın başarısı dikkat çekmektedir. Bu iki ülkenin başarısının arkasında ülke ekonomisine fon sağlayan özel sektörün de 
etkisi olduğu düşünülmektedir. İspanya ise güçlü bir finansal gelişmişliğe sahip olsa da yüksek borçları ve faiz ödemeleri sebebi ile ekonomik performans açısından OECD ülkeleri içerisinde son sıralarda yer almaktadır. Genel olarak gelişmekte olan ülkeler, doğal olarak gelişmiş ülkelere göre daha başarısızdır.

Çalışmada kullanılan Westerlund eşbütünleşme analizi sonuçlarına göre, uzun dönemde finansal gelişme ile ekonomik performans arasında çift yönlü ilişki olduğu tespit edilmiştir. Dinamik sabit etkiler modeli ile tahmin edilen hata düzeltme mekanizmaları çalışmakta, kısa dönemde meydana gelen dengesizlikler uzun dönemde giderilmektedir. Ekonomik performansın finansal gelişme üzerindeki kısa ve uzun dönem etkilerinin yönü belirsizdir. Ancak finansal gelişme ekonomik performansı kısa dönemde pozitif etkilerken uzun dönemde negatif etkilemektedir. Çünkü finansal gelişme kısa dönemde sağladığı fonlar ile tüketime dayalı büyümeyi arttırmakta bu da ekonomik performans üzerinde olumlu etki yaratmaktadır. Buna rağmen uzun dönemde bu fonların reel üretime dönüşmemesi, girişimciler tarafından kullanılmaması, vadesi gelen borçların ve faizlerin ödenmesi ve artan geri ödeme riski ile birlikte yükselen faiz oranları gibi sebepler, finansal gelişmenin ekonomik performansı uzun dönemde negatif etkilemesine neden olmaktadır.

Ülkeler veya hükümetler uzun dönemde ekonomik performanslarını arttırmayı hedefliyorlarsa, elde ettikleri finansal kaynakları reel yatırımlara dönüştürmelidir. Yüksek borçlanmaya dayalı kısa vadeli büyüme politikası izleyen ülkelerin uzun dönemde ekonomik performanslarının kötüleştiği İspanya ve Yunanistan örneklerinden görülmektedir. Beşeri sermayeye ve Ar-Ge harcamalarına önem veren ülkeler ve bu ülkeleri destekleyen özel sektör, ekonomik performansin ve istikrarın artmasında etkili olmaktadır. Bu sebeple özel sektör-kamu işbirliğini arttıran projelerin geliştirilmesi ve desteklenmesi gerektiği düşünülmektedir. 


\title{
EXTENDED ABSTRACT
}

\section{Financial Development and Economic Performance Relationship: An Analysis For OECD Countries}

\author{
Hatice Armutcuoğlu Tekin - Mert Ural \\ Adnan Menderes University - Dokuz Eylül University
}

In this study, the long-term relationship between financial development and economic performance was investigated for OECD countries in the period of 2006-2016. Panel cointegration analysis was preferred as the method of the study. Therefore Westerlund Cointegration Analysis was applied. The error correction mechanism was then investigated by means of the dynamic constant effects estimator. Long and short term coefficients were estimated. Besides, descriptive analysis techniques have been investigated for reasons of success of countries through tables. While financial development is examined in relation to economic performance, measurement of economic performance with misery index differentiates the study from other studies.

Misery index is composed of variables which is growth, inflation, unemployment and interest rate. In order to compare the country performances of Hanke, the misery index adapted by Barro (1999) was used in this study. Financial development index, IMF database; three key indicators from the World Bank database; long-term interest rates were obtained from Eurostat and OECD database.

It can be said that countries with high financial development are more successful in terms of economic performance. The success of Switzerland and Japan among the OECD countries is noteworthy. Behind the success of these two countries, the private sector, which provides funds to the country's economy, is thought to have an impact. It ranks first in terms of Swiss financial development index. This success has been the result of $\mathrm{R}$ $\& \mathrm{D}$ activities and banking market privacy policies. Japan's lifelong employment policy, in-company promotion activities increased competition and influenced the development of the private sector. Although Spain has a strong financial development, it ranks among the OECD countries in 
terms of economic performance due to its high debts and interest payments. Greece and Turkey are the countries having high public debt and high interest payments that. In general, developing countries are more unsuccessful than naturally developed countries. It is noteworthy that the growth performance of developing countries in OECD countries is high when it is analyzed only in terms of growth.

When the literature review is examined, the relationship between financial development and economic performance is analyzed according to different macroeconomic indicators. For this reason, the literature review of the study has been examined in four different sections: the effect of financial development on growth, unemployment, inflation and long-term interest rates. While financial development has a positive effect on growth through increasing funds, the negative effects of the crisis in these markets are spreading faster due to the increasing globalization. The effect of financial development on growth depends on the impact of the financial system on entrepreneurs. There are also studies that have different results when examined in the long and short term. In the financial developmentinflation relationship, they concluded that both variables negatively affect each other. When the effect on unemployment is examined, the results is different according to the position and structure of the country. No study has been found to examine the impact of financial development on interest.

According to the results of Westerlund cointegration analysis used in the study, it was determined that there is a double relationship between financial development and economic performance in the long run. The predicted error correction mechanisms are studied with the dynamic constant effects model and the short term imbalances are eliminated in the long term. The direction of the short and long-term effects of economic performance on financial development is unclear. However, financial development affects the economic performance in the short term and affects it negatively in the long term. Because financial development increases consumption-based growth with the funds it provides in the short term, this has a positive effect on economic performance. Nevertheless, the reasons such as the fact that these funds are not transformed into real production in the long term, not being used by entrepreneurs, the payment of borrows and interests and the rising interest rates due to the increased risk 
of repayment cause the financial performance to negatively impact the economic performance in the long term.

If countries or governments are aiming to increase their economic performance in the long term, they should convert their financial resources into real investments. The short-term growth policy based on high borrowing is seen in the examples of Spain and Greece, where the economic performance of the following countries worsened in the long run. Countries that give importance to human capital and $\mathrm{R} \& \mathrm{D}$ expenditures and the private sector supporting these countries are effective in increasing economic performance and stability. For this reason, it is thought that projects which increase the private-public cooperation should be developed and supported.

\section{Kaynakça / References}

Acaravc1, A., Öztürk, İ. ve Kakilli Acaravc1, S. (2007). Finace-growth nexus: Evidence from Turkey. International Research Journal of Finance and Economics, 11, 30-40.

Ağır, H., Peker, O. ve Kar, M. (2009). Finansal gelişmenin belirleyicileri üzerine bir değerlendirme: literatür taraması. BDDK Bankacılık ve Finansal Piyasalar, 3, 31-61.

Al, İ. ve Baday Yıldız, E. (2019). Türkiye'nin 2006-2017 dönemi makroekonomik performansı: Sihirli kare yaklaşımı. Atatürk Üniversitesi İktisadi ve İdari Bilimler Dergisi, 33, 303-320.

Alesina, A. ve Summers, L.H. (1993). Central bank independence and macroeconomic performance: some comparative evidence. Journal of Money, Credit and Banking, 25, 151-162.

Altıntaş, H.ve Ayrıçay Y. (2010). Türkiye'de finansal gelişme ve ekonomik büyüme ilişkisinin sınır testi yaklaşımıyla analizi: 1987-2007. Anadolu Üniversitesi Sosyal Bilimler Dergisi, 10, 71-98.

Asher, M. A., Defina, R. H. ve Thanawala, K. (1993). The misery index: Only part of the story. Challenge, 36, 58-62.

Aslan, Ö. ve Korap, H. L. (2006). Türkiye'de finansal gelişme ekonomik büyüme ilişkisi. Muğla Üniversitesi Sosyal Bilimler Enstitüsü Dergisi (İLKE), 17, 1-20. 
Ateş, M.Y. (2003). Mucizeden Duraklamaya Japon Ekonomisi: Sonuçlar, Sebepler. Uluslararası Ekonomik Sorunlar Dergisi, 9. 03.02.2019 tarihinde http://www.mfa.gov.tr/mucizeden-duraklamaya-japonekonomisi_-sonuclar_-sebepler.tr.mfa adresinden erişildi.

Azariadis, C. ve Smith, B. D. (1996). Private information, money, and growth: indeterminacy, fluctuations and the Mundell-Tobin effect. Journal of Economic Growth, 1, 309-332.

Barro, R. J. (1999). Reagan vs. Clinton: Who's the Economic Champ?. Business Week. 03.10.2017 tarihinde https://scholar.harvard.edu/barro/publications/reagan-vs-clinton-whos-economicchamp adresinden erişildi.

Beck, T., Levine, R. ve Loayza, N. (2000). Finance and sources of growth. Journal of Financial Economics, 58, 261-300.

Benlialper, A., Cömert, H. ve Düzçay, G. (2016). 2002 sonrası Türkiye ekonomisinin performansı: karşılaştırmalı bir analiz. ODTÜ Gelişme Dergisi, 43, 65-110.

Boyd, John H., Levine, Ross and Smith, Bruce D. (1996). Inflation and financial market performance. Federal Reserve Bank of Minneapolis Research Department Working Paper, 573D. 01.02.2018 tarihinde https://www.researchgate.net/profile/Ross_Levine/publication/5029595_Inflation_and_financial_market_performance/links/53f3690d0cf2dd48950cbab5/Inflation-and-financialmarket-performance.pdf adresinden erişildi.

Bozkurt, K. ve Balmumcu, Ö. (2018). Beşeri sermaye ve ekonomik büyüme: gelişmekte olan ülkeler için bir panel veri analizi. Uluslararası İktisadi ve İdari İncelemeler Dergisi, Prof. Dr. Harun Terzi Özel Sayısı, 391-406.

Breusch, T. S. ve Pagan, A. R. (1980). The lagrange multiplier and its applications to model specification in econometrics. The Review of Economic Studies, 47, 239-253.

Darrat, A. F., Elkhal, K. ve McCallum, B. (2006). Finance and macroeconomic performance. Emerging Markets, Finance and Trade, 42, 528.

Demir, Y., Öztürk, E. ve Albeni, M. (2007). Türkiye'de finansal piyasalar ile ekonomik büyüme ilişkisi. Kahramanoğlu Mehmet Bey Üniversitesi Sosyal ve Ekonomik Araştırmalar Dergisi, 2007, 438-455. 
Doğan, H. (2002). Finansal derinleşme ve ekonomik büyüme ilişkisi: Türkiye örneği. İktisat, İşletme ve Finans, 17, 60-71.

Durusu Çiftçi, D., İspir, M.S. ve Yetkiner, H. (2016). Financial development and economic growth: some theory and more evidence. Journal of Policy Modelling, 39, 290-306.

Eğilmez, M. (2018). Sefalet endeksi ve Türkiye. 03.09.2018 tarihinde http://www.mahfiegilmez.com/2018/06/sefalet-endeksi-veturkiye.html adresinden erişildi.

Ekinci, A. ve Gül, E. (2007). Türkiye'de yurtiçi tasarruflar ve ekonomik büyüme arasındaki ilişki: uygulamalı bir analiz (1960-2004). Dumlupınar Üniversitesi Sosyal Bilimler Dergisi 19, 167-184.

Friedman, M. (1937). The use of ranks to avoid the assumption of normality implicit in the analysis of variance. Journal of the American Statistical Association, 32, 675-701.

Gatti, D., Rault, C. and Vaubourg A. (2012). Unemployment and finance: How do financial and labor market factors interact?. Oxford Economic Papers, 64, 464-489.

Gökdeniz, İ., Erdoğan, M. ve Kalyüncü ,K. (2003). Finansal piyasaların ekonomik büyümeye etkisi ve Türkiye örneği (1989-2002). Gazi Üniversitesi Ticaret ve Turizm Eğitim Fakültesi Dergisi, 1, 101117.

Göktaş, P., Pekmezci, A.ve Bozkurt, K. (2018). Ekonometrik serilerde uzun dönem eşbütünleşme ve kısa dönem nedensellik ilişkileri: Eviews ve STATA uygulamaları. Ankara: Gazi Kitabevi.

Graff, M. ve Karmann, A. (2006). What determines the finance-growth nexus? Emprical evidence for threshold models. Journal of Economics, 87, 127-157.

Gurley, J. G. and Shaw, E. S. (1955). Financial aspects of economic development. The American Economic Review, 45, 515-538.

Güneş, S. (2013). Finansal gelişmişlik ve ekonomik büyüme arasındaki nedensellik testi: Türkiye örneği. Doğuş Üniversitesi Dergisi, 14, 73-85.

Güngör, B. ve Yılmaz, Ö. (2008). Finansal piyasalardaki gelişmelerin iktisadi büyüme üzerine etkileri: Türkiye için VAR modeli. Atatürk Üniversitesi İktisadi ve İdari Bilimler Dergisi, 22, 173-193. 
Güran, M. C. ve Tosun, M. U. (2005). Türkiye ekonomisinin makro ekonomik performansı: 1951-2003 dönemi için paremetrik olmayan bir ölçüm. Ankara Üniversitesi SBF Dergisi, 60, 89-115.

Hanke's Misery Index (2017), 01.06.2018 tarihinde https://thumbor.forbes.com/thumbor/960x0/smart/https\%3A\%2F\%2Fblosimages.forbes. com\%2Fsevehanke\%2Ffiles\%2F2018\%2F02\%2FHankes-AnnualMisery-Index-2017.jpg\%3Fwidth\%3D960 adresinden erişilmiştir.

Hsueh, S., Hu, Y. ve Tu C. (2013). Economic growth and financial development in asian countries: A bootsrap panel Granger causality analysis. Economic Modelling 32, 294-301.

Huang, Y. (2005). What determines financial development?. Bristol Economics Discussion Paper, 05/580,1-45. Department of Eco-nomics, University of Bristol UK. 03.10.2017 tarihinde http://www.efm.bris.ac.uk/economics/working_papers/pdffiles/dp05580.pdf adresinden erişilmiştir.

Huybens, E. and Smith, B. D.(1998). Financial market frictions, monetary policy, and capital accumulation in a small open economy. Journal of Economic Theory, 81, 353-400.

IFFC A, (2018). 20.12.2018 tarihinde http://iifc.com.tr/zurih-bolgesel-finans-merkezi/ adresinden erişilmiştir.

IFFC B, (2018). 20.12.2018 tarihinde http://iifc.com.tr/madrid-bolgesel-finans-merkezi/ adresinden erişilmiştir.

IFFC C, (2018). 20.12.2018 tarihinde http://iifc.com.tr/new-yorkuluslararasi-finans-merkezi/ adresinden erişilmiştir.

IMF (2018), 12.12.2018 tarihinde http://data.imf.org/?sk=F8032E80-B36C43B1-AC26-493C5B1CD33B adresinden erişilmiştir.

İbrahim, M. H. (2011). Stock market development and macroeconomic performans in Thailand. Inzinerine Ekonomika-Engineering Economics, 22, 230-240.

Kanberoğlu, Z. (2014). Finansal sektör gelişimi ve işsizlik: Türkiye örneği. Ekonomik ve Sosyal Araştırmalar Dergisi, 10, 83-93.

Kappel, V. (2009). Financial development and economic performance. ETH Zürich Research Collection Doctoral Thesis. 04.02.2017 tarihinde https://www.research-collection.ethz.ch/handle/20.500.11850/15-1275 adresinden erişilmiştir. 
Kar, M. ve Pentecost, E. J. (2000). Financial development and eco-nomic growth in Turkey: Further evidence on the causality is-sue. Lougborough University Economic Research Paper 00/27. 01.08.2018 tarihinde https://www.researchgate.net/publication/228581900_Financial_development_and_economic_growth_in_Turkey_further_evidence_on_the_causality_issue adresinden erişilmiştir.

Kar, M., Peker, O. ve Kaplan, M. (2008). Trade liberalization financial development and economic growth in the long run: The case of Turkey. South East European Journal of Economics and Business, 3, 28-38.

Katzenstein, P. J., (1980). Capitalism in one country? Switzerland in the international economy. International Organization, 34, 507-540.

Kenton, W. (2018), 30.04.2018 tarihinde https://www.investopedia.com/terms $/ \mathrm{m} /$ miseryindex.asp adresinden erişilmiştir.

Kibritçioğlu, A. (2007). A comparison of macroeconomic performances of governments in Turkey, 1987-2007. MPRA Paper No: 3662. 01. 01. 2019 tarihinde http://mpra.ub.uni-muenchen.de/3962/ adresinden erişilmiştir.

King, R. G. and Levine, R.(1993). Finance, entrepreneurship and growth theory and evidence. Journal of Monetary Economics. 32, 513-542.

Law, S. H. and Singh, N. (2013). Does too much finance harm economic growth. Journal of Banking \& Finance, 41, 36-44.

Mercan, M. Ve Peker, O. (2013). Finansal gelişmenin ekonomik büyümeye etkisi. Eskişehir Osmangazi Üniversitesi İ̈BF Dergisi, 8, 93-120.

Misery Indeks US, (2018). 16.08.2018 tarihinde http://www.miseryindex.us/about.aspx. adresinden erişilmiştir.

Moesen, W. and Cherchye, L. (1998). The macroeconomic performance of nations measurement and perception. Center of Economic Studies Discussion Paper Series DPS 98.22, 1-29.

Molho, L. E. (1986). Interest rates, saving, and investment in developing countries: A Re-examination of the McKinnon-Shaw hypotheses. Staff Papers (International Monetary Fund), 33, 90-116.

Moore, B.J., (1986). Inflation and financial deepening. Journal of De-velopment Economics, 20, 125-133.

Müslümov, A. and Gürsoy, C. T.(2000). Stock markets and economic growth: A casualty test. Dogus University Journal, 2000, 124-131. 
Rajan, R. G. ve Zingales, L. (2003). The great reversals: The politics of financial development in the twentieth century. Journal of Financial Economics, 69, 5-50.

Sağlam, Y. ve Erataş Sönmez, F. (2017). Finansal gelişme ve ekonomik büyüme arasındaki ilişki: Avrupa geçiş ekonomileri örneği. Eskişehir Osmangazi Üniversitesi İ̈BF Dergisi, 12, 121-140.

Sahay, R., Cihak, M., N’Diaye, P. vd. (2015). Rethinking financial deepening: Stability and growth in emerging markets. IMF Staff Discussion Notes (SDNs), 12.12.2018 tarihinde https://www.imf.org/external/pubs/ft/sdn/2015/sdn1508.pdf adresinden erişilmiştir.

Schreft, S. L. and Smith, B. D. (1997). Money, banking, and capital formation. Journal of Economic Theory, 73, 157-182.

Setterfield, M. (2009). An index of macroeconomic performance. International Review of Applied Economics, 23, 625-649.

Seven, Ü. (2015). Finansal gelişmişlik ve ekonomik büyüme. Türkiye Sermaye Piyasaları Birliği Gösterge/Yaz 2015 Dergisi, 44-63. 03.02.2017 tarihinde https://www.academia.edu/13547740/Finansal_Geli\%C5\%9Fmi\%C5\%9Flik_ve_Ekonomik_B\%C3\%BCy\% $\mathrm{C} 3 \% \mathrm{BCme}$ adresinden erişilmiştir.

Sığrı, Ü. (2006). Japonların kültürel özellikleri bağlamında: Yönetsel, ekonomik ve sosyal süreçlerinin analizi. İstanbul Ticaret Üniversitesi Sosyal Bilimler Dergisi, 9, 29-47.

Suki, L. (2006) Remittances in Serbia and financial sector development: Business opportunities and priorities for investment. New York: Center on Globalization and Sustainable Development, The Earth Institute at Columbia University.

Şanlısoy, S. ve Çetin, M. (2016). Türkiye ekonomisinde hükümetlerin ekonomik performanslarının TOPSIS yöntemi ile ölçülmesi. Sosyoekonomi, 24, 65-83.

Oskay, C. (2018). Küresel kriz sonrası kırılgan beşli ülkelerin makroekonomik performansları üzerine karşılaştırmalı bir analiz. ICOPEC 2018: 10 Years After the Great Recession: Orthodox versus Heterodox Economics 9. International Conference on Political Economy. 2018/26. 
Öztürk, N., Barışık, S. ve Kılıç Darıcl, H. (2010). Gelişmekte olan piyasalarda finansal derinleşme ve büyüme ilişkisi: Panel veri analizi. ZKÜ Sosyal Bilimler Dergisi, 6, 95-119.

Pesaran, M. H. (2007). A simple panel unit root test in the presence of cross section dependence. Journal of the Applied Econometrics, 22, 265312.

Ticaret Bakanlığ1 (2018). 12.08.2018 tarihinde https://ticaret.gov.tr/yurtdisi-teskilati/avusturalya/avustralya/ulke-profili/genelekonomik-durum adresinden erişilmiştir.

Ticaret Bakanlığ1 (2018). 02.02.2018 tarihinde https://ticaret.gov.tr/yurtdisi-teskilati/avrupa/ispanya/ulke-profili/ekonomik-gorunum/genel-ekonomik-durum adresinden erişilmiştir.

Ünalmış, D. (2002). The causality between financial development and economic growth: The case of Turkey. The Central Bank of The Republic of Turkey Research Department Working Paper No:3. 08.04.2018 tarihinde http://unpan1.un.org/intradoc/groups/public/documents/APCITY/UNPAN018315.pdf adresinden erişilmiştir.

Yerdelen Tatoğlu, F. (2013a). Panel veri ekonometrisi: Stata uygulamalı. İstanbul: Beta Yayıncilı.

Yerdelen Tatoğlu, F. (2013b). İleri panel veri analizi: Stata uygulamalı. İstanbul: Beta Yayıncllık.

\section{Kaynakça Bilgisi / Citation Information}

Armutcuoğlu-Tekin, H. ve Ural, M. (2019). Finansal gelişme ve ekonomik performans ilişkisi: OECD ülkeleri için bir analiz. OPUSUluslararası Toplum Araştırmaları Dergisi, 11(18), 43-77. DOI: 10.26466/opus. 535427 